\title{
Seventh Annual Report on Federal Agency Use of Voluntary Consensus Standards and Conformity Assessment
}

\author{
Kevin L. McIntyre \\ Michael B. Moore
}

Standards Coordination and Conformity Group

Standards Services Division

Technology Services 
NISTIR 7118

\title{
Seventh Annual Report on Federal Agency Use of Voluntary Consensus Standards and Conformity Assessment
}

\author{
Kevin L. McIntyre \\ Michael B. Moore
}

Standards Coordination and Conformity Group

Standards Services Division

Technology Services

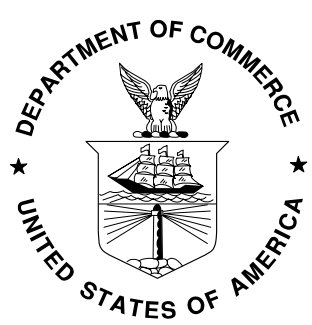

U.S. DEPARTMENT OF COMMERCE

Donald L. Evans, Secretary

TECHNOLOGY ADMINISTRATION

Phillip J. Bond, Under Secretary of Commerce for Technology NATIONAL INSTITUTE OF STANDARDS AND TECHNOLOGY 


\section{Table of Contents}

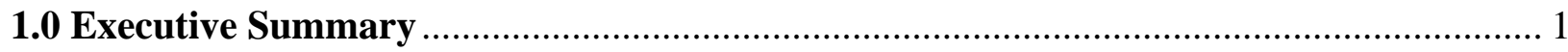

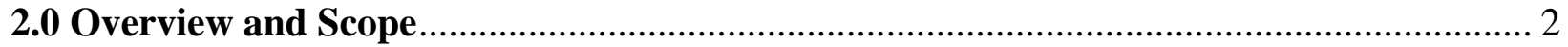

3.0 Federal Agency Use of Standards......................................................................... 3

3.1 Government-Unique Standards Used in lieu of Private Sector Standards..............................

3.2 Federal Agency Use of Private Sector Standards ............................................................6

3.3 Private Sector Standards Substituted for Government-Unique Standards.............................6

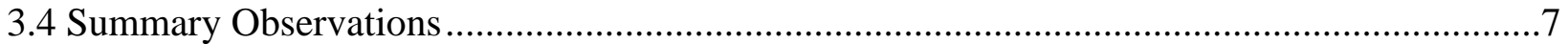

4.0 Federal Participation in Private Sector Bodies ........................................................ 7

4.1 Federal Agency Participation in Private Sector Standards Development Activities ................7

4.2 Federal Agency Employees Participating in Private Sector Standards Bodies .......................8

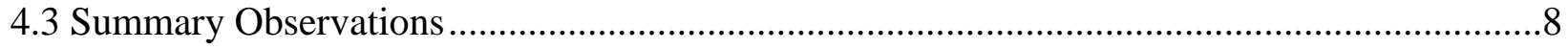

5.0 Federal Agency Conformity Assessment Activity ................................................. 8

6.0 Evaluation of the Effectiveness of OMB Circular A-119 ........................................ 9

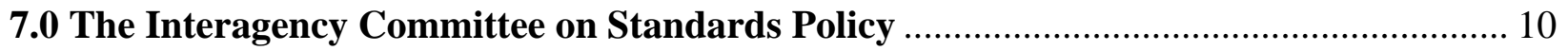

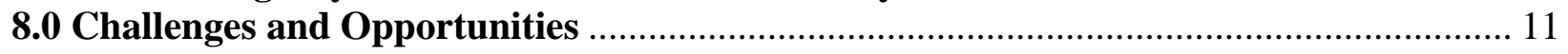

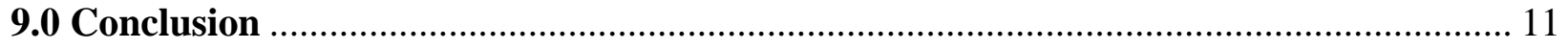

APPENDICES

Appendix A: $\quad$ FY 2003 List of Reporting Federal Agencies .............................................. A-1

Appendix B: FY 2003 Federal Agency Activities Related to Use of Private Sector

Standards and Conformity Assessment ........................................................................

Appendix C: Government-Unique Standards Used in lieu of Voluntary Consensus

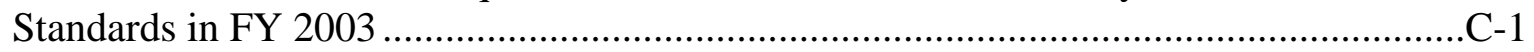

Appendix D: The "Standards.Gov" Website .............................................................. D-1 


\section{Summary Report on Federal Agency Use of Voluntary Consensus Standards and Conformity Assessment Activities for FY 2003}

\subsection{Executive Summary}

This summary report is provided to the Office of Management and Budget (OMB) by the National Institute of Standards and Technology (NIST) in compliance with OMB Circular A-119 and Public Law 104-113, the National Technology Transfer and Advancement Act (NTTAA). It describes activities related to the use of voluntary consensus standards and conformity assessment practices by agencies of the Federal government during FY 2003 as required by Paragraph 9 of the Circular.

This report presents the standards and conformity assessment activities of 25 Federal agencies. Reported data show that overall Federal agencies continue to look to the private sector to fulfill government needs rather than creating new government-unique standards. Since FY 1997, Federal agencies have adopted nearly 2,500 private sector standards in support of their regulatory, procurement and policy activities.

For FY 2003, Federal agencies reported 400 new uses of private sector standards. In addition, during the same period agencies substituted 185 private sector standards for government-unique standards. This is a clear demonstration of the progress made by agencies in complying with the NTTAA and Circular A-119. It indicates that, overall, agencies are increasingly looking to the private sector to fulfill government's needs rather than create new government-unique standards.

Agency reporting on the number of government-unique standards used in lieu of private sector standards shows an incremental increase in FY 2003; with only nine new uses reported. New uses by agencies of government-unique standards in lieu of private sector standards have declined steadily each year since FY 1999.

Federal agencies reported participation in 433 private sector standards developing organizations during FY 2003. This is the largest number recorded since 2001 when NIST began collecting this data. The number of agency staff participating in standards activities was 3,568, an increase of $11 \%$ over the previous reporting period. Even so, private sector standards developers assert that there continue to be areas where greater Federal agency participation is necessary to ensure government input on important standards-related issues.

For their part, Federal agencies report that maintaining their current levels of participation in standards developing organizations is becoming increasingly difficult. Competing organizational priorities, dwindling budget resources and anticipation in coming years of accelerated staff losses due to retirement and downsizing are just some of the reasons for concern in this area among agency Standards Executives. 
Federal agencies continue to make advances in their ability to assess their standardsrelated activities and to make accurate reports of their activities for incorporation into this annual report. NIST is focusing its efforts on improving information sharing among Federal agencies as well as between the public and private sector, and on developing training programs to acquaint agency staff with their responsibilities under the NTTAA.

\subsection{Overview and Scope}

This summary report is provided to the Office of Management and Budget (OMB) by the National Institute of Standards and Technology (NIST) in compliance with OMB Circular A-119. It describes activities related to the use of voluntary consensus standards and conformity assessment practices by agencies of the Federal government during FY 2003 as required by Paragraph 9 of the Circular. The account of federal activities summarized in this document was compiled from reports submitted to NIST by federal agencies also in compliance with Paragraph 9 of the OMB Circular and Section 12 of the NTTAA. First signed into law on March 7, 1996, the NTTAA directs federal government agencies to achieve greater reliance on voluntary consensus standards developed by the private sector and decreased dependence on government-unique standards developed by and for the government. It also directs that federal agency personnel participate in the activities of voluntary consensus standards developing organizations in order to help ensure that standards produced in the private sector are more likely to be appropriate for use by federal agencies. These policies had been reflected for many years in OMB Circular A-119, and the enactment of the NTTAA codified these policies into statute and reinforced them.

This report presents the standards and conformity assessment activities of twenty-five (25) federal agencies as listed in Appendix A. Data for the Department of Homeland Security (DHS) is not included in this report, as the Department was not fully formed and operational with respect to its standards management operations in time to file a submission for FY 2003 for inclusion herein. Consequently, reports from the Federal Emergency Management Agency and the National Communications System, both of which reported as independent agencies in years past, as well as the US Coast Guard, which formerly reported under the Department of Transportation, are not included in this report, as those agencies were all subsumed under the newly established DHS during FY 2003.

This summary report represents a shift in reporting methodology from prior submissions made by NIST in compliance with the Act and the Circular. In response to comments received on the content and structure of past reports, NIST has attempted to prepare a shorter, more focused report that is more useful and informative for the reader. Supplemental information including individual agency submissions that were published in the past as appendices to NIST reports can be obtained online at www.standards.gov or by contacting NIST directly. 


\subsection{Federal Agency Use of Standards}

According to OMB Circular A-119, federal agencies must use voluntary consensus standards, both domestic and international, in their regulatory and procurement activities in lieu of government-unique standards. An agency has the discretion to decline to use existing voluntary consensus standards if the agency determines that use of such standards is inconsistent with applicable law or otherwise impractical. According to paragraph 6 a.(1) and (2) of OMB Circular A-119:

"Use" means incorporation of a standard in whole, in part, or by reference for procurement purposes, and the inclusion of a standard in whole, in part, or by reference in regulation(s).

"Impractical" includes circumstances in which such use would fail to serve the agency's program needs; would be infeasible; would be inadequate, ineffectual, inefficient, or inconsistent with agency mission; or would impose more burdens, or would be less useful, than the use of another standard.

The Circular also directs agencies to establish a process for ongoing review of their use of standards for purposes of updating such use, including substitution of private sector standards for government-unique standards wherever possible.

The stated policies of the OMB Circular are thus intended to reduce to a minimum the reliance by agencies on government-unique standards. The Circular also states that its policies do not create the basis for discrimination in agency procurement or regulatory activities among standards developed in the private sector, whether or not they are developed by voluntary consensus standards bodies. Historically, federal agencies have in fact used other private sector standards (classified by the Circular as non-consensus standards, industry standards, company standards and de facto standards). In reporting the full measure of their efforts at minimizing government-unique standards, agencies have typically reported to NIST their activities in these areas as well. Consequently, the information contained in this report addresses the use of standards and participation in standards development activities of organizations described interchangeably either as non-government or private sector standards developers. Either of these terms can be taken to include voluntary consensus standards as well as the other classifications of standards listed above.

\subsection{Government-Unique Standards Used in Lieu of Private Sector Standards}

According to paragraph 6 of OMB Circular A-119, the heads of agencies "must transmit to OMB through NIST an explanation of the reason(s) for using government-unique standards in lieu of voluntary consensus standards." After careful review of data for FY 2003 and past reporting periods, NIST and OMB have taken steps in this report to account for inconsistent reporting across the agencies that has in the past presented a less than accurate picture of this important metric. To explain briefly, some agencies in past years have counted the number of private sector standards not used instead of the 
government-unique standards that were introduced. For example, a single governmentunique standard used in lieu of five private sector standards was often reported as five government-unique standards used. For the first time in this report, each governmentunique standard is listed (and counted) only once along with all of the corresponding private sector standards not used. Appendix C contains a complete listing of reported government-unique standards used in lieu of private sector standards for FY 2003, as well as the associated rationales for such use provided by the agencies. Secondly, further examination of the government-unique standards reported in this category has revealed that some standards were listed previously when no alternative private sector standards existed. In the absence of a private sector standard not used, these government-unique standards need not be reported and have therefore been removed from the list. Finally, while some agencies report use of a government-unique standard in the first year that it is used and in each subsequent year until such use is rescinded, other agencies report use of a government-unique standard only in the first year of its use. For this report, an effort was made to normalize the reported data in a manner consistent with the spirit of the NTTAA.

Table 3.1 illustrates the cumulative use of standards from FY 1997 to present by agency as well as the number introduced and withdrawn each year. Appendix C contains a list of the 72 government-unique standards and justifications reported between FY 1997 and FY 2003 that are still in use.

Table 3.1 Government-unique Standards Used in Lieu of Private Sector Standards FY 1997 - FY 2003

\begin{tabular}{|c|c|c|c|c|c|c|c|}
\hline Agency & $\begin{array}{c}\text { FY } \\
\mathbf{1 9 9 7}\end{array}$ & $\begin{array}{c}\text { FY } \\
\mathbf{1 9 9 8}\end{array}$ & $\begin{array}{c}\mathrm{FY} \\
\mathbf{1 9 9 9}\end{array}$ & $\begin{array}{c}\mathrm{FY} \\
\mathbf{2 0 0 0}\end{array}$ & $\begin{array}{c}\mathrm{FY} \\
\mathbf{2 0 0 1}\end{array}$ & $\begin{array}{c}\mathrm{FY} \\
\mathbf{2 0 0 2}\end{array}$ & $\begin{array}{c}\mathrm{FY} \\
\mathbf{2 0 0 3}\end{array}$ \\
\hline DOD & $*$ & $*$ & $*$ & $*$ & $*$ & $*$ & $*$ \\
\hline HHS & 3 & 3 & 3 & 3 & 3 & 3 & 3 \\
\hline HUD & & & & 2 & 2 & 2 & 2 \\
\hline DOL & & & & & 1 & 2 & 4 \\
\hline DOT & 1 & 2 & 2 & 2 & 2 & 3 & 3 \\
\hline EPA & & 4 & 29 & 30 & 40 & 45 & 50 \\
\hline GSA & & & & 3 & 2 & 2 & 3 \\
\hline NASA & $*$ & $*$ & $*$ & $*$ & $*$ & $*$ & $*$ \\
\hline NARA & & & & 1 & 1 & 1 & 1 \\
\hline CPSC & & & & 1 & 1 & 1 & 2 \\
\hline \multicolumn{2}{|c|}{ GPO } & & & 4 & 4 & 4 & 4 \\
\hline New Uses & +4 & +5 & +25 & +12 & +11 & +7 & +9 \\
\hline Discontinued & & & & & -1 & & \\
\hline Total in Use & $\mathbf{4}$ & $\mathbf{9}$ & $\mathbf{3 4}$ & $\mathbf{4 6}$ & $\mathbf{5 6}$ & $\mathbf{6 3}$ & $\mathbf{7 2}$ \\
\hline
\end{tabular}

Agencies were not asked to report in FY 1997 those government-unique standards already in place at the onset of the NTTAA and OMB Circular A-119 reporting requirements. Consequently, there is no data presently available to indicate how many government-unique standards introduced more than seven years ago are still in use that 
could possibly be withdrawn and replaced by more current, relevant and cost-saving voluntary consensus standards. Therefore, NIST will encourage agencies to intensify their efforts in future years to review government-unique standards uses that are five years old or older to determine if suitable voluntary consensus standards are now available for substitution. Also, for future reporting periods NIST will call on agencies to specifically report ongoing use of previously reported government-unique standards such as those listed in Appendix $\mathrm{C}$ and to identify additions, deletions, and substitutions of government-unique standards that occur during the reporting period as is captured in Table 3.1.

Table 3.1 indicates that agencies continue to develop a minimal number of governmentunique standards each year. Agencies report that these additions are necessary in order to fulfill demands of higher performance specifications and measurements as well as to accommodate highly specialized technologies.

OMB Circular A-119 allows federal agencies to report the number of private sector standards they have used on either a categorical or transactional basis as outlined in Paragraph 11 and Paragraph 12 of the Circular, respectively. In short, under the categorical option, agencies that make extensive use of standards in procurement activities are not required to list individually all of the government-unique standards they used in lieu of private sector standards during the period. Thus, the numbers represented in Table 3.1 do not fully encompass all of the government-unique standards used in lieu of private sector standards by federal agencies during FY 2003. Only two agencies, the Department of Defense (DOD) and the National Aeronautics and Space Administration (NASA), opted to report their use of government-unique standards in lieu of private sector standards on a categorical basis for FY 2003. However, both DOD and NASA have always reported this way for prior reporting periods. Therefore, the data points in Table 3.1 consistently represent government-unique standards used in lieu of private sector standards for the rest of reporting agencies.

The practice of using government-unique standards on the part of federal agencies will necessarily continue because of the highly specialized applications of technology (i.e., military, space travel, national security) in which federal agencies are involved. However, the incidence of new uses of government-unique standards has stabilized at a very low rate; only nine new standards were used for the first time during this reporting period. Agencies that continue to use government standards developed in the past instead of available voluntary consensus standards state the need to apply and to adhere to higher performance specifications and measurements than are available through commercial and/or other consensus standards. Therefore, while the government-unique standards listed may appear at face value to be duplicative of available private sector standards, the health, environmental and safety benefits of their use balance the costs. Examples include the Department of Transportation's (DOT) Performance-Based Brake Testing standards for large trucks and buses, the Environmental Protection Agency's (EPA) Methods for testing air quality, and the Department of Health and Human Services/Food and Drug Administration’s (HHS/FDA) Guidelines on Aseptic Processing. 


\subsection{Federal Agency Use of Private Sector Standards}

This measure provides a general indication of the frequency with which government agencies used private sector standards during the reporting period. In any reporting year, the total number of private sector standards used by all government agencies will vary based largely on current operational priorities for that period. As with the previous measures, this one can be affected by changes in the accuracy with which federal agencies are able to determine and report their use of standards during the reporting period.

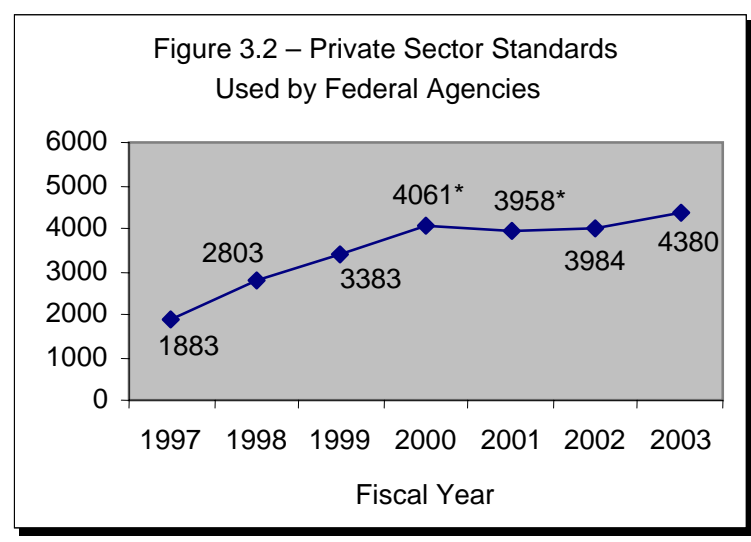

* Due to lack of available data, amounts for FY 2000 and FY 2001 contain estimated Private Sector Standards use for Department of Interior.

As illustrated by Figure 3.2, the total number of private sector standards in use by federal agencies has grown rather steadily since the onset of agency reporting under the NTTAA. (The sharp increase indicated in FY 2000 was due largely to a reported increase of more than 1500 VCS used by the Department of the Interior. While this irregularity is thought to be a reporting error, Interior is unable to confirm a more accurate figure.)

In FY 2003, changes in standards use varied widely on an agency-by-agency basis; however, the positive net change of nearly 400 new uses of private sector standards again demonstrates the progress made by federal agencies in complying with the NTTAA and Circular A-119. The positive trend seen in the chart indicates overall that, as needs arise within federal agencies for new standards, the agencies are increasingly looking to the private sector to fulfill government's needs rather than create new government-unique standards.

\subsection{Private Sector Standards Substituted for Government-Unique Standards}

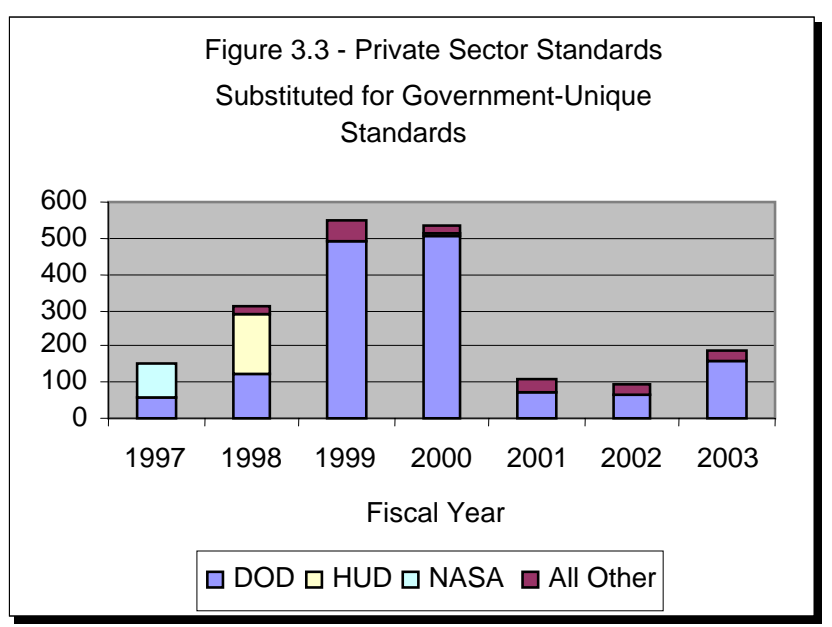

Once again, a significant number of private sector standards were substituted for government-unique standards during the reporting period, which attests to the fulfillment of Section 12 of the NTTAA (P.L. 104113). These figures are represented graphically in Figure 3.3. As in previous years, the Department of Defense was responsible for the largest number of substitutions. Since 1999, DOD has accounted for the majority of the private sector standards substitutions in any given 
year. In FY 2003, DOD substitutions accounted for about 85 percent of the total. The standards substituted address a diverse set of technologies including metals and alloys, and manufactured parts.

\subsection{Summary Observations}

It is important to caution the reader that reliance upon numbers alone for an understanding of federal agency standards use can be misleading. For example, an increase in the use of government-unique standards used in lieu of private sector standards may not signal a negative development if national priorities such as homeland security require such use. Likewise, the use of a management system standard such as ISO 9000 or ISO 14000 can be a far more significant event and can have a much more profound effect on a federal agency's activities, including its regulated and/or affected procurement communities, than use of a specific test method. Yet, the use of each standard may be counted only once by a reporting agency. At any rate, while there is much more substance to federal use of standards than can be discerned through a cursory review of reported figures, the overall trends are clear-federal agencies are increasing their reliance upon private sector standards.

\subsection{Federal Participation in Private Sector Bodies}

OMB Circular A-119 states that federal agencies "must consult with voluntary consensus standards bodies, both domestic and international, and must participate with such bodies in the development of voluntary consensus standards when consultation and participation is in the public interest and is compatible with their missions, authorities, priorities, and budget resources." The Circular goes on to declare that "agency support provided to a voluntary consensus standards activity must be limited to that which clearly furthers agency and departmental missions, authorities, priorities, and is consistent with budget resources."

\section{$\underline{4.1 \text { Federal Agency Participation in Private Sector Standards Development Activities }}$}

Federal agencies reported participation in 433 private sector standards developing organizations during FY 2003. This is the largest number of non-government standards developing organizations with federal agency participants recorded since 2001 when NIST began collecting this data. This total includes ANSI-accredited voluntary consensus standards developers, trade associations and industry consortia. The list also contains both domestic and international organizations. In addition to participating at the committee level, federal representatives also serve in various other ways within these organizations, sometimes serving in leadership roles that include secretariats, office holders and board members. Nevertheless, private sector standards developers assert that even greater federal agency participation is necessary in order to bring forth government input on important standards-related matters. 


\subsection{Federal Agency Employees Participating in Private Sector Standards Bodies}

In the aggregate, federal agencies once again reported higher net numbers of participation in standards developing activities in FY 2003, another indicator of the increased attention being paid by agencies to standards activities and use. The gains are largely attributable to more complete and accurate reporting of employee participation on the part of a handful of responding agencies.

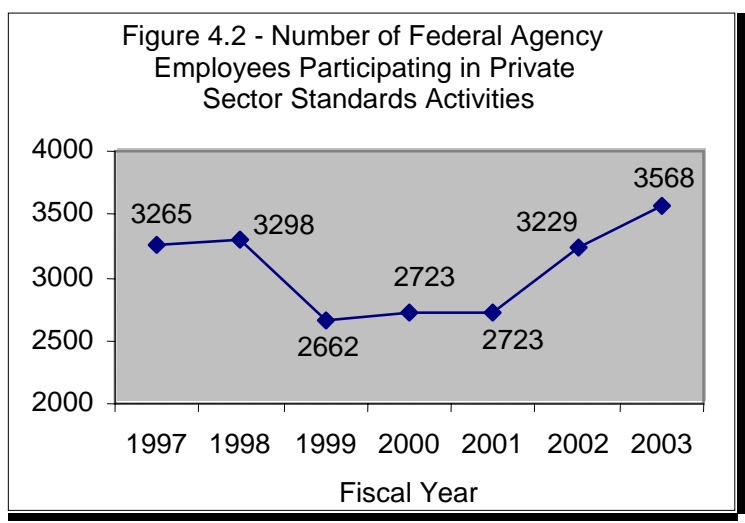

\section{$\underline{4.3 \text { Summary Observations }}$}

As stated above, the reported increases in recent years of federal agency involvement in private sector standards development activities signifies an overall improved capability on the part of federal agencies to gauge and report their activity levels in these areas. Some clear benefits of better accounting are that agencies can better manage their existing resources, and they are able to more effectively focus their efforts on standards that further mission-related priorities.

Anecdotally, federal agencies assert that maintaining their current levels of participation in standards developing organizations is becoming increasingly difficult. Competing organizational priorities, dwindling budget resources and anticipation in coming years of accelerated losses due to retirement of experienced staff are just some of the reasons for concern in this area among agency Standards Executives. It is also true that these factors are more prevalent in some agencies than in others, resulting in noticeable variability across the agencies with respect to the current status of their individual efforts to implement the requirements of the NTTAA and OMB Circular A-119.

\subsection{Federal Agency Conformity Assessment Activity}

Conformity assessment includes all activities concerned with determining directly or indirectly that relevant requirements in standards or regulations are fulfilled. Conformity assessment includes: sampling and testing; inspection; certification; management systems assessment and registration; accreditation of the competence of the aforementioned activities and recognition of an accreditation program's capability. The NTTAA directs NIST to coordinate government standards activities and conformity assessment activities with private sector standards activities and conformity assessment activities. In accordance with OMB Circular A-119, NIST issued guidance ${ }^{1}$ to federal agencies for the purpose of eliminating unnecessary duplication and complexity in the development and promulgation of conformity assessment requirements and measures.

\footnotetext{
${ }^{1} 15$ CFR Part 287, Guidance on Federal Conformity Assessment Activities, Federal Register: August 10, 2000 (Volume 65, Number 155)
} 
There are several examples of agencies using existing public and private sector conformity assessment systems to reduce the duplication of programs and associated costs. For instance, NIST cooperates with the National Cooperation for Laboratory Accreditation (NACLA) through the NIST/ NACLA Memorandum of Understanding which states that "NIST and NACLA will encourage the use by government and the private sector of such accreditation bodies by informing them of the NACLA recognition process and inviting their participation in that process." In another example, the Department of Energy has endorsed the mission and vision of NACLA, part of which involves encouraging DOE laboratories and organizations to become users of the NACLA accreditation body recognition process and to join NACLA as member organizations. Other examples of ongoing public-private cooperation in conformity assessment activities include the following:

- EPA currently recognizes the American Industrial Hygiene Association and the American Association for Laboratory Accreditation (A2LA) as accrediting organizations for its National Lead Laboratory Accreditation Program (NLLAP).

- A2LA and NIST's National Voluntary Laboratory Accreditation Program (NVLAP) are approved accreditation bodies under the U.S. Federal Communications Commission (FCC) program that requires manufacturers and suppliers of personal computers and computer peripherals who intend to use a "Declaration of Conformity" on their products to have the products tested by an accredited Electromagnetic Compatibility (EMC) laboratory.

Federal agencies continue to participate in a variety of conformity assessment activities that are either conducted by private sector organizations or are government-run activities that encourage private sector participation. A number of federal agencies are working jointly with other agencies and non-governmental organizations in the development of conformity assessment policies and guidelines.

\subsection{Evaluation of the Effectiveness of OMB Circular A-119}

OMB Circular A-119 provides an opportunity for federal agencies to offer commentary on the effectiveness of the Circular. The remarks offered by federal agencies for FY 2003 were mostly positive. Some examples of those comments are paraphrased below:

- The Consumer Product Safety Commission stated that during FY 2003, the Commission's efforts to enhance voluntary safety standards development were complemented by the overall federal policy set forth in the Circular.

- The Department of Defense affirmed that the A-119 policy mandating that government agencies review their respective voluntary consensus standards programs at least once a year is an excellent means of determining if agencies are relying on government-unique standards to a greater extent than is necessary.

- The National Aeronautics and Space Administration stated that the Circular continues to provide stimulus for NASA's efforts to "enhance the use of Voluntary Consensus Standards, challenge the need for NASA-unique Technical 
Standards requirements, and improve its Technical Standards System.” As a result, NASA has increased its participation with Voluntary Consensus Standards bodies in standards activities by 10 percent from FY 2002.”

On the other hand, some agencies voiced a desire for more precise instructions on how to report their use of standards. These and other issues surrounding federal agencies' ability to effectively comply with the Circular will be addressed by the Interagency Committee on Standards Policy (ICSP) during FY 2004.

\subsection{The Interagency Committee on Standards Policy}

As set out in Section 13 of OMB Circular A-119, the Interagency Committee on Standards Policy (ICSP) is directed to advise the Secretary of Commerce and other Executive Branch agencies in standards policy matters. The Committee reports to the Secretary of Commerce through the Director of NIST. The ICSP seeks to promote effective and consistent standards policies in furtherance of U.S. domestic and foreign goals and to foster cooperative participation by the Federal government and U.S. industry and other private organizations in standards activities, including the related activities of product testing, quality system registration, certification, and accreditation.

Chaired by NIST, the committee had as many as 45 members during FY 2003, including agency Standards Executives and their alternates, NIST support staff and representation from OMB. Six agencies had vacant Standards Executive positions. In May 2003, the ICSP, through the Secretary of Commerce, made requests of five federal agency heads to appoint Standards Executives to fill existing vacancies on the ICSP and to achieve representation for the newly formed Department of Homeland Security. The ICSP Chair plans to request through the Secretary one additional appointment to represent the newly formed Access Board, formerly the Architectural and Transportation Barrier Compliance Board, an independent Federal Board originally created by Congress in 1973. The use of government-unique and private sector standards as well as conformity assessment activities will very likely figure in the programs of both the DHS and the Access Board; therefore, membership on and coordination with the ICSP should prove advantageous for both organizations and for the ICSP as a whole.

The ICSP met three times in FY 2003 at various locations in the Washington Metropolitan Area. The following examples are but a handful of the various topics discussed by the committee at those meetings:

- The importance of standards in support of homeland security objectives, and the addition of representation from the newly formed Department of Homeland Security;

- Collaboration with the private sector through the Homeland Security Standards Panel established by the American National Standards Institute (ANSI);

- Ramifications for federal agencies stemming from the SBCCI, Inc. v. Veeck case;

- Private sector concerns regarding use by multiple federal agencies of the Leadership in Energy and Environmental Design (LEED) Green Building Rating 
System for environmentally sustainable buildings;

- Various discussions among committee members regarding improved methods of selecting standards for use, improved management of standards activities, and streamlined annual activity reporting.

\subsection{Challenges and Opportunities}

In order to comply successfully with the Act and the Circular, federal agencies must work externally to increase their use of private sector standards and to increase their participation in private sector standards development activities. At the same time, federal agencies must improve internally their ability to assess their activities and to make accurate reports of their activities for incorporation into the NTTAA Annual Reports. Clearly, federal agencies are making advances in both of these areas.

At the same time, federal agencies continue to deal constructively with significant challenges to their efforts to fully implement the requirements of the NTTAA.

Diminishing assets and competing organizational priorities have caused agencies to make difficult decisions regarding resource allocations as they try to maintain support for standards-related activities at levels necessary to carry out their missions. In addition, agencies regularly experience personnel turnover at all organizational levels due to reorganizations, accelerating retirements among senior level career personnel, and normal attrition. These changes make it very difficult for federal agencies to retain high-level managers who appreciate the importance of standards and who visibly support standardsrelated activities. Likewise, federal agencies struggle to retain knowledge of standards policies, responsibilities and practices at the staff level.

In an effort to address at least some of these challenges, NIST is developing training programs with the goal of acquainting federal agency leaders, managers and staff with their roles and responsibilities under the NTTAA as well as the benefits to government of NTTAA implementation. Under this initiative, practical guidance will also be offered in effective methods of managing and reporting standards activities. NIST also intends to create a handbook that contains useful and concise information for federal employees who make decisions regarding use of standards.

In a further effort to improve information sharing among federal agencies as well as between government and the private sector, NIST has created an Internet portal located at www.standards.gov. A major goal of this portal is to provide a one-stop, e-government location for information related to the use of voluntary consensus standards in government. It can also serve as a forum for providing ongoing, practical guidance to agencies on standards-related matters. Appendix D is provided to introduce readers to the store of information that is available at this site. NIST welcomes any suggestions on content and format improvements that might improve the usability of this portal.

\subsection{Conclusion}

This year's report is evidence that agencies are committed to carrying out Section 12 of 
the NTTAA, which was enacted to encourage the Federal government to rely on private sector, voluntary consensus standards wherever possible. There is ample evidence to suggest that the Federal government as a whole is improving incrementally from year-toyear both in its use of private sector standards and in the level of its participation in private sector standards development activities. From FY 1997-FY 2003, the government has used nearly 2,000 private sector standards in place of government-unique standards. Furthermore, federal agencies are developing very few government-unique standards, and federal agencies overall are getting better at reporting the full extent of their standards-related activities in an accurate and timely manner. Private sector stakeholders continue to seek additional participation to meet their needs for government input in important standards development activities.

For additional information, individual agency report submissions may be obtained online at www.standards.gov or by contacting the Standards Coordination and Conformity Group within Technology Services at NIST. 


\section{Appendix A: FY 2003 List of Reporting Federal Agencies}

Note: This report presents the standards and conformity assessment activities of twentyfive (25) federal agencies as listed below. Data for the Department of Homeland Security (DHS) is not included in this report, as the Department was not fully formed and operational with respect to its standards management operations in time to file a submission for FY 2003. Consequently, reports from the Federal Emergency Management Agency and the National Communications System, both of which reported as independent agencies in years past, as well as the US Coast Guard, which formerly reported under the Department of Transportation, are not included in this report, as those agencies were all subsumed under the newly established DHS during FY 2003.

\section{Agency}

Department of Agriculture

Department of Commerce

Department of Defense

Department of Energy

Department of Education

Department of Health and Human Services

Department of Housing and Urban Development

Department of the Interior

Department of Justice

Department of Labor

Department of State

Department of Transportation

Department of the Treasury

Department of Veterans Affairs

Environmental Protection Agency

Agency for International Development

General Services Administration

National Archives and Records Administration

National Aeronautics and Space Administration

National Science Foundation

Consumer Product Safety Commission

Federal Communications Commission

Federal Trade Commission

Nuclear Regulatory Commission

Government Printing Office

\section{Acronym}

USDA

DOC

DOD

DOE

ED

HHS

HUD

DOI

DOJ

DOL

DOS

DOT

TRES

VA

EPA

USAID

GSA

NARA

NASA

NSF

CPSC

FCC

FTC

NRC

GPO 


\section{Appendix B: Federal Agency Activities Related to Use of Private Sector Standards and Conformity Assessment}

\begin{tabular}{|c|c|c|c|c|c|c|c|}
\hline $\begin{array}{c}\text { I } \\
\text { Agency }\end{array}$ & $\begin{array}{c}\text { II } \\
\text { Government- } \\
\text { unique } \\
\text { standards in } \\
\text { use in lieu of } \\
\text { voluntary } \\
\text { consensus } \\
\text { standards }\end{array}$ & $\begin{array}{c}\text { III } \\
\text { Voluntary } \\
\text { consensus } \\
\text { standards } \\
\text { substituted } \\
\text { for } \\
\text { government- } \\
\text { unique } \\
\text { standards in } \\
\text { FY } 2003\end{array}$ & $\begin{array}{c}\text { IV } \\
\text { Voluntary } \\
\text { consensus } \\
\text { standards } \\
\text { in use in } \\
\text { FY } 2003\end{array}$ & $\begin{array}{c}\mathrm{V} \\
\text { Employee } \\
\text { participation } \\
\text { in voluntary } \\
\text { consensus } \\
\text { standards } \\
\text { bodies in } \\
\text { FY } 2003\end{array}$ & $\begin{array}{c}\text { VI } \\
\text { Change } \\
\text { from } \\
\text { previous } \\
\text { year }\end{array}$ & $\begin{array}{c}\text { VII } \\
\text { Voluntary } \\
\text { consensus } \\
\text { standards } \\
\text { bodies with } \\
\text { agency } \\
\text { participation } \\
\text { in FY } 2003\end{array}$ & $\begin{array}{c}\text { VIII } \\
\text { Change } \\
\text { from } \\
\text { previous } \\
\text { year }\end{array}$ \\
\hline USDA & 0 & 0 & 163 & 106 & 24 & 42 & -9 \\
\hline DOC & 0 & 0 & 0 & 415 & -24 & 118 & -47 \\
\hline DOD & $*$ & 156 & 8803 & 450 & -11 & 55 & 0 \\
\hline DOE & 0 & 0 & 1187 & 674 & -7 & 85 & 28 \\
\hline ED & 0 & 0 & 17 & 2 & 0 & 1 & 0 \\
\hline HHS & 3 & 11 & 663 & 623 & 108 & 165 & 126 \\
\hline HUD & 2 & 1 & 300 & 10 & 0 & 5 & 0 \\
\hline DOI & 0 & 0 & 242 & 645 & 345 & 25 & 6 \\
\hline DOJ & 0 & 0 & 1 & 5 & 0 & 1 & -1 \\
\hline DOL & 4 & 0 & 117 & 61 & 1 & 16 & 1 \\
\hline DOS & 0 & 0 & 0 & 0 & 0 & 0 & 0 \\
\hline DOT & 3 & 0 & 323 & 167 & -9 & 30 & -24 \\
\hline TRES & 0 & 0 & 99 & 3 & -63 & 3 & -5 \\
\hline VA & 0 & 0 & 0 & 4 & -10 & 17 & -3 \\
\hline EPA & 50 & 0 & 109 & 44 & 2 & 21 & -1 \\
\hline USAID & 0 & 0 & 0 & 0 & 0 & 0 & 0 \\
\hline GSA & 3 & 0 & 391 & 25 & -19 & 26 & 2 \\
\hline NARA & 1 & 16 & 52 & 13 & 0 & 10 & -2 \\
\hline NASA & $*$ & 1 & 266 & 144 & 13 & 33 & -3 \\
\hline NSF & 0 & 0 & 0 & 3 & 3 & 7 & 7 \\
\hline CPSC & 2 & 0 & 0 & 31 & 2 & 7 & -1 \\
\hline FCC & 0 & 0 & 0 & 5 & 0 & 7 & 0 \\
\hline FTC & 0 & 0 & 0 & 0 & 0 & 0 & 0 \\
\hline NRC & 0 & 0 & 117 & 136 & -8 & 15 & 0 \\
\hline GPO & 4 & 0 & 126 & 2 & 2 & 4 & 4 \\
\hline Totals & 72 & 185 & 4380 & 3568 & 349 & & \\
\hline
\end{tabular}

* Agencies reporting on a category basis per OMB Circular A-119, Section 12. 


\section{Appendix C: Government-Unique Standards Used in lieu of Voluntary Consensus Standards in FY 2003}

Note: Government-unique standards denoted by $\left({ }^{*}\right)$ indicate instances of use reported for the first time in FY 2003.

\begin{tabular}{|c|c|c|c|c|}
\hline & Agency & $\begin{array}{l}\text { Government-Unique } \\
\text { Standard }\end{array}$ & $\begin{array}{c}\text { Voluntary } \\
\text { Consensus } \\
\text { Standard }\end{array}$ & Rationale Provided by Agency \\
\hline 1 & HHS & $\begin{array}{l}\text { FDA Guidelines on } \\
\text { Aseptic Processing (1987) }\end{array}$ & $\begin{array}{l}\text { ISO 13408-1 - Aseptic } \\
\text { Processing of Health } \\
\text { Care Products, Part 1, } \\
\text { General Requirements }\end{array}$ & $\begin{array}{l}\text { FDA/CBER is not using the ISO standard } \\
\text { because the applicability of these requirements is } \\
\text { limited to only portions of aseptically } \\
\text { manufactured biologics and does not include } \\
\text { filtration, freeze-drying, sterilization in place, } \\
\text { cleaning in place, or barrier-isolator technology. } \\
\text { There are also significant issues related to } \\
\text { aseptically produced bulk drug substance that } \\
\text { are not included in the document }\end{array}$ \\
\hline \multirow[t]{3}{*}{2} & \multirow[t]{3}{*}{ HHS } & \multirow[t]{3}{*}{$\begin{array}{l}\text { FR Notice dated June 17, } \\
1994 \text { Tentative Final } \\
\text { Monograph for Health } \\
\text { Care Antiseptic Drug } \\
\text { Products; Proposed Rule }\end{array}$} & $\begin{array}{l}\text { ASTM Standard E1115 } \\
\text { - Test Method for } \\
\text { Evaluation of Surgical } \\
\text { Hand Scrub } \\
\text { Formulations }\end{array}$ & $\begin{array}{l}\text { Sensitivity and bias of the ASTM Standard has } \\
\text { not been established. }\end{array}$ \\
\hline & & & $\begin{array}{l}\text { ASTM Standard } \\
\text { E1173-93 - Standard } \\
\text { Test Method of an } \\
\text { Evaluation of } \\
\text { Preoperative, } \\
\text { Precatheterization, or } \\
\text { Preinjection Skin } \\
\text { Preparations }\end{array}$ & $\begin{array}{l}\text { Sensitivity and bias of the ASTM Standard has } \\
\text { not been established. }\end{array}$ \\
\hline & & & $\begin{array}{l}\text { ASTM Standard } \\
\text { E1174-00 - Standard } \\
\text { Test Method for the } \\
\text { Evaluation of the } \\
\text { Effectiveness of Health } \\
\text { Care Personnel or } \\
\text { Consumer Handwash } \\
\text { Formulations }\end{array}$ & $\begin{array}{l}\text { Sensitivity and bias of the ASTM Standard has } \\
\text { not been established. }\end{array}$ \\
\hline 3 & HHS & $\begin{array}{l}\text { National Standard Format } \\
\text { (NSF) }\end{array}$ & ANSI X12 837 & $\begin{array}{l}\text { The NSF is used widely across the health care } \\
\text { payment industry and has become a defacto } \\
\text { national standard. However, the Centers for } \\
\text { Medicare and Medicaid Services (CMS) have } \\
\text { directed their contractors to discontinue use of } \\
\text { the NSF standard and replace it with ANSI X12 } \\
837 .\end{array}$ \\
\hline 4 & HUD & $\begin{array}{l}24 \text { CFR } 200.935 \text {-- } \\
\text { Administrator } \\
\text { qualifications and } \\
\text { procedures for HUD } \\
\text { building products } \\
\text { certification programs. }\end{array}$ & $\begin{array}{l}\text { ANSI A119.1 N - } \\
\text { Recreation Vehicles }\end{array}$ & $\begin{array}{l}\text { HUD Building-Product Standards \& } \\
\text { Certification Programs. HUD was required by } \\
\text { legislation to "establish federal construction and } \\
\text { safety standards for manufactured homes and to } \\
\text { authorize manufactured home safety research } \\
\text { and development." Recently, HUD retained a }\end{array}$ \\
\hline
\end{tabular}




\begin{tabular}{|c|c|c|c|c|}
\hline & Agency & $\begin{array}{l}\text { Government-Unique } \\
\text { Standard }\end{array}$ & $\begin{array}{l}\text { Voluntary } \\
\text { Consensus } \\
\text { Standard }\end{array}$ & Rationale Provided by Agency \\
\hline & & & & $\begin{array}{l}\text { private consensus body (NFPA) to update and } \\
\text { modernize the Manufactured Home Standards. } \\
\text { At the conclusion of the development process, } \\
\text { NFPA will submit the revised standard to HUD } \\
\text { for regulatory adoption. }\end{array}$ \\
\hline 5 & HUD & $\begin{array}{l}24 \text { CFR } 3280- \\
\text { Manufactured Home } \\
\text { Construction and Safety } \\
\text { Standards }\end{array}$ & $\begin{array}{l}\text { ANSI A119.1, } \\
\text { Recreation Vehicles, } \\
\text { and NFPA 501C, } \\
\text { Standard on } \\
\text { Recreational Vehicles. }\end{array}$ & $\begin{array}{l}\text { HUD-Unique Manufactured Home Construction } \\
\text { \& Safety Standards. HUD was required by } \\
\text { legislation to "establish federal construction and } \\
\text { safety standards for manufactured homes and to } \\
\text { authorize manufactured home safety research } \\
\text { and development." Recently, HUD retained a } \\
\text { private consensus body (NFPA) to update and } \\
\text { modernize the Manufactured Home Standards. } \\
\text { At the conclusion of the development process, } \\
\text { NFPA will submit the revised standard to HUD } \\
\text { for regulatory adoption. }\end{array}$ \\
\hline 6 & DOL & $\begin{array}{l}\text { Electric Motor-Drive } \\
\text { Equipment rule }\end{array}$ & $\begin{array}{l}\text { IEEE Standard 242- } \\
1986 \text { Recommended } \\
\text { Practice for Protection } \\
\text { and Coordination of } \\
\text { Industrial and } \\
\text { Commercial Power } \\
\text { Systems (IEEE Buff } \\
\text { Book) } \\
\text { NFPA } 70 \text { - National } \\
\text { Electrical Code }\end{array}$ & $\begin{array}{l}\text { The MSHA rule is a design-specific standard. } \\
\text { The NFPA and IEEE standards were used as a } \\
\text { source for the rule; however, the exact } \\
\text { requirements of the rule were tailored to apply } \\
\text { specifically to electric circuits and equipment } \\
\text { used in the coal mining industry. }\end{array}$ \\
\hline $7 *$ & DOL & $\begin{array}{l}\text { Exit Routes, Emergency } \\
\text { Action Plans, and Fire } \\
\text { Prevention Plans, } 29 \text { CFR } \\
\text { 1910, Subpart E }\end{array}$ & $\begin{array}{l}\text { Life Safety Code, } \\
\text { NFPA 101-2000 }\end{array}$ & $\begin{array}{l}\text { The OSHA standard addresses only workplace } \\
\text { conditions whereas the NFPA Life Safety Code } \\
\text { goes beyond workplaces. However, in the final } \\
\text { rule OSHA stated that it had evaluated the } \\
\text { NFPA Standard 101, Life Safety Code, (NFPA } \\
\text { 101-2000) and concluded that it provided } \\
\text { comparable safety to the Exit Route Standards. } \\
\text { Therefore, the Agency stated that any employer } \\
\text { who complied with the NFPA 101-2000 instead } \\
\text { of the OSHA Standard for Exit Routes would be } \\
\text { in compliance. }\end{array}$ \\
\hline $8^{*}$ & DOL & $\begin{array}{l}\text { Sanitary Toilets in Coal } \\
\text { Mines, } 30 \text { CFR 71, } \\
\text { Subpart E }\end{array}$ & $\begin{array}{l}\text { Non-Sewered Waste } \\
\text { Disposal Systems-- } \\
\text { Minimum } \\
\text { Requirements, ANSI } \\
\text { Z4.3-1987 }\end{array}$ & $\begin{array}{l}\text { The ANSI standard was not incorporated by } \\
\text { reference because certain design criteria allowed } \\
\text { in the ANSI standard, if implemented in an } \\
\text { underground coal mine, could present health or } \\
\text { safety hazards. For instance, combustion or } \\
\text { incinerating toilets could introduce an ignition } \\
\text { source which would create a fire hazard. For } \\
\text { certain other design criteria found in the ANSI } \\
\text { standard, sewage could seep into the } \\
\text { groundwater, or overflow caused by rain or run- } \\
\text { off could contaminate portions of the mine. }\end{array}$ \\
\hline 9 & DOL & Steel Erection Standards & $\begin{array}{l}\text { ANSI A10.13, Steel } \\
\text { Erection; ASME/ANSI }\end{array}$ & $\begin{array}{l}\text { Many consensus standards were relied upon for } \\
\text { various provisions in the final rule, but there was }\end{array}$ \\
\hline
\end{tabular}




\begin{tabular}{|c|c|c|c|c|}
\hline & Agency & $\begin{array}{l}\text { Government-Unique } \\
\text { Standard }\end{array}$ & $\begin{array}{l}\text { Voluntary } \\
\text { Consensus } \\
\text { Standard }\end{array}$ & Rationale Provided by Agency \\
\hline & & & $\begin{array}{l}\text { B30 series Cranes } \\
\text { standards }\end{array}$ & $\begin{array}{l}\text { no one consensus standard available that covered } \\
\text { all of the topics covered by OSHA's final rule. }\end{array}$ \\
\hline 10 & DOT & $\begin{array}{l}\text { Brake Performance, } 49 \\
\text { CFR 393.52, - FMCSA's } \\
\text { Performance-Based Brake } \\
\text { Testers (PBBTs) } \\
\text { requirement. }\end{array}$ & $\begin{array}{l}\text { SAE J667 - Brake Test } \\
\text { Code Inertia } \\
\text { Dynamometer } \\
\text { (cancelled February, } \\
\text { 2002) } \\
\text { SAE J1854 - Brake } \\
\text { Force Distribution } \\
\text { Performance Guide - } \\
\text { Trucks and Buses }\end{array}$ & $\begin{array}{l}\text { FMCSA used government-unique standards in } \\
\text { lieu of voluntary consensus standards when it } \\
\text { implemented its final rule to allow inspectors to } \\
\text { use performance-based brake testers (PBBTs) to } \\
\text { check the brakes on large trucks and buses for } \\
\text { compliance with federal safety standards and to } \\
\text { issue citations when these vehicles fail (67 FR } \\
51770 \text {, August 9, 2002). The FMCSA evaluated } \\
\text { several PBBTs during a round robin test series to } \\
\text { assess their functional performance and potential } \\
\text { use in law enforcement. The standard, a specific } \\
\text { configuration of brake forces and wheel loads on } \\
\text { a heavy-duty vehicle, was used to evaluate the } \\
\text { candidate PBBTs and their operating protocols. } \\
\text { The agency's rationale for use of the } \\
\text { government-unique standards was to verify that } \\
\text { these measurements and new technology could } \\
\text { be used by law enforcement as an alternative to } \\
\text { stopping distance tests or on-road deceleration } \\
\text { tests. PBBTs are expected to save time and their } \\
\text { use could increase the number of commercial } \\
\text { motor vehicles that can be inspected in a given } \\
\text { time. Only PBBTs that meet specifications } \\
\text { developed by the FMCSA can be used to } \\
\text { determine compliance with the Federal Motor } \\
\text { Carrier Safety Regulations. The final rule } \\
\text { represents a culmination of agency research that } \\
\text { began in the early 1990s. }\end{array}$ \\
\hline 11 & DOT & $\begin{array}{l}63 \text { FR 17976; April 13, } \\
1998 \text { - Product Safety } \\
\text { Signs and Labels }\end{array}$ & $\begin{array}{l}\text { ANSI Z535.4 - ANSI } \\
\text { Requirements for Color } \\
\text { Coded Header } \\
\text { Messages for the } \\
\text { Different Levels of } \\
\text { Hazard }\end{array}$ & $\begin{array}{l}\text { Since agency labeling decisions are highly } \\
\text { dependent on the facts regarding the specific } \\
\text { hazard being addressed, NHTSA anticipates } \\
\text { making case-by-case determinations of the } \\
\text { extent to which it should follow voluntary } \\
\text { standards versus information from focus groups } \\
\text { and other sources. NHTSA will rely on its own } \\
\text { expertise and judgment in making } \\
\text { determinations under the NTTAA and the } \\
\text { statutory provisions regarding vehicle safety } \\
\text { standards. }\end{array}$ \\
\hline 12 & DOT & $\begin{array}{l}\text { Air Bag Warning Label } \\
\text { (1997) }\end{array}$ & $\begin{array}{l}\text { ANSI } \\
\text { ISO }\end{array}$ & $\begin{array}{l}\text { The Air Bag Warning Label uses yellow as the } \\
\text { background color, instead of orange, in } \\
\text { accordance with an ANSI standard, and uses a } \\
\text { graphic developed by Chrysler Corporation to } \\
\text { depict the hazards of being too close to an air } \\
\text { bag, instead of the graphic recommended by the } \\
\text { ISO. These decisions were based on focus group } \\
\text { testing sponsored by the agency which strongly } \\
\text { indicated that these unique requirements would } \\
\text { be far more effective with respect to safety than }\end{array}$ \\
\hline
\end{tabular}




\begin{tabular}{|c|c|c|c|c|}
\hline & Agency & $\begin{array}{c}\text { Government-Unique } \\
\text { Standard }\end{array}$ & $\begin{array}{c}\text { Voluntary } \\
\text { Consensus } \\
\text { Standard }\end{array}$ & Rationale Provided by Agency \\
\hline & & & & the industry standards. \\
\hline 13 & EPA & $\begin{array}{l}40 \text { CFR } 89 \text { - Control of } \\
\text { Emissions from New and } \\
\text { In-Use Non-Road } \\
\text { Compression Ignition } \\
\text { Engines }\end{array}$ & $\begin{array}{l}\text { ISO } 8178 \text { - } \\
\text { Reciprocating Internal } \\
\text { Combustions Engines, } \\
\text { Exhaust Emission } \\
\text { Measurement }\end{array}$ & $\begin{array}{l}\text { Procedures would be impractical because they } \\
\text { rely too heavily on reference testing conditions. } \\
\text { Agency decides instead to continue to rely on } \\
\text { procedures outlined in } 40 \text { CFR Part } 90 \text {. }\end{array}$ \\
\hline 14 & EPA & $\begin{array}{l}40 \text { CFR } 90 \text { - Control of } \\
\text { Emission from Non-Road } \\
\text { Spark Ignition Engines at } \\
\text { or below 19KV }\end{array}$ & $\begin{array}{l}\text { ISO } 8178- \\
\text { Reciprocating Internal } \\
\text { Combustions Engines, } \\
\text { Exhaust Emission } \\
\text { Measurement }\end{array}$ & $\begin{array}{l}\text { Procedures would be impractical because they } \\
\text { rely too heavily on reference testing conditions. } \\
\text { Agency decides instead to continue to rely on } \\
\text { procedures outlined in } 40 \text { CFR Part } 90 \text {. }\end{array}$ \\
\hline 15 & EPA & $\begin{array}{l}\text { 40 CFR } 92 \text { - Control of } \\
\text { Air Pollution from } \\
\text { Locomotives and } \\
\text { Locomotive Engines }\end{array}$ & $\begin{array}{l}\text { ISO } 8178 \text { - } \\
\text { Reciprocating Internal } \\
\text { Combustions Engines, } \\
\text { Exhaust Emission } \\
\text { Measurement }\end{array}$ & $\begin{array}{l}\text { Procedures would be impractical because they } \\
\text { rely too heavily on reference testing conditions. } \\
\text { Agency decides instead to continue to rely on } \\
\text { procedures outlined in } 40 \text { CFR Part } 90 \text {. }\end{array}$ \\
\hline \multirow[t]{2}{*}{16} & \multirow[t]{2}{*}{ EPA } & \multirow[t]{2}{*}{$\begin{array}{l}\text { EPA Method } 1 \text { - Traverse } \\
\text { Points, Stationary Sources }\end{array}$} & $\begin{array}{l}\text { ASTM D3154-00, } \\
\text { Standard Method for } \\
\text { Average Velocity in a } \\
\text { Duct (Pitot Tube } \\
\text { Method) }\end{array}$ & $\begin{array}{l}\text { 1. The standard appears to lack in quality } \\
\text { control and quality assurance requirements. It } \\
\text { does not include the following: (1) Proof that } \\
\text { openings of standard pitot tube have not plugged } \\
\text { during the test; (2) if differential pressure gauges } \\
\text { other than inclined manometers (e.g., } \\
\text { magnehelic gauges) are used, their calibration } \\
\text { must be checked after each test series; and (3) } \\
\text { the frequency and validity range for calibration } \\
\text { of the temperature sensors. 2. They are too } \\
\text { general, too broad, or not sufficiently detailed to } \\
\text { assure compliance with EPA regulatory } \\
\text { requirements. }\end{array}$ \\
\hline & & & $\begin{array}{l}\text { ASTM D3154-91 } \\
\text { (1995), "Standard } \\
\text { Method for Average } \\
\text { Velocity in a Duct } \\
\text { (Pitot Tube Method)" }\end{array}$ & $\begin{array}{l}\text { Is too general, too broad, or not sufficiently } \\
\text { detailed to assure compliance with EPA } \\
\text { regulatory requirements. }\end{array}$ \\
\hline \multirow[t]{2}{*}{17} & \multirow[t]{2}{*}{ EPA } & \multirow[t]{2}{*}{$\begin{array}{l}\text { EPA Method } 2 \text { - Velocity } \\
\text { and S-type Pitot }\end{array}$} & $\begin{array}{l}\text { ASTM 3796-90 (1998), } \\
\text { "Standard Practice for } \\
\text { Calibration of Type S } \\
\text { Pitot Tubes" }\end{array}$ & $\begin{array}{l}\text { The standard lacked sufficient quality control } \\
\text { specifications to ensure meeting the regulatory } \\
\text { levels required in the rule; the standard also } \\
\text { includes detection limits not consistent with the } \\
\text { rule. Rule: "National Emission Standards for } \\
\text { Hazardous Air Pollutants; Engine Test } \\
\text { Cells/Stands" }\end{array}$ \\
\hline & & & $\begin{array}{l}\text { ASTM D3464-96 } \\
\text { (2001), Standard Test } \\
\text { Method Average } \\
\text { Velocity in a Duct } \\
\text { Using a Thermal } \\
\text { Anemometer }\end{array}$ & $\begin{array}{l}\text { Applicability specifications are not clearly } \\
\text { defined, e.g., range of gas composition, } \\
\text { temperature limits. Also, the lack of supporting } \\
\text { quality assurance data for the calibration } \\
\text { procedures and specifications, and certain } \\
\text { variability issues that are not adequately } \\
\text { addressed by the standard limit EPA's ability to } \\
\text { make a definitive comparison of the method in } \\
\text { these areas. }\end{array}$ \\
\hline
\end{tabular}




\begin{tabular}{|c|c|c|c|c|}
\hline & Agency & $\begin{array}{l}\text { Government-Unique } \\
\text { Standard }\end{array}$ & $\begin{array}{l}\text { Voluntary } \\
\text { Consensus } \\
\text { Standard }\end{array}$ & Rationale Provided by Agency \\
\hline & & & $\begin{array}{l}\text { ISO 10780:1994, } \\
\text { Stationary Source } \\
\text { Emissions-- } \\
\text { Measurement of } \\
\text { Velocity and Volume } \\
\text { Flowrate of Gas } \\
\text { Streams in Ducts }\end{array}$ & $\begin{array}{l}\text { The standard recommends the use of an } \\
\text { L-shaped pitot, which historically has not been } \\
\text { recommended by EPA. The EPA specifies the } \\
\text { S-type design, which has large openings that are } \\
\text { less likely to plug up with dust. }\end{array}$ \\
\hline & & & $\begin{array}{l}\text { ASTM D3154-00, } \\
\text { Standard Method for } \\
\text { Average Velocity in a } \\
\text { Duct (Pitot Tube } \\
\text { Method) }\end{array}$ & $\begin{array}{l}\text { 1. The standard appears to lack in quality } \\
\text { control and quality assurance requirements. It } \\
\text { does not include the following: (1) Proof that } \\
\text { openings of standard pitot tube have not plugged } \\
\text { during the test; (2) if differential pressure gauges } \\
\text { other than inclined manometers (e.g., } \\
\text { magnehelic gauges) are used, their calibration } \\
\text { must be checked after each test series; and (3) } \\
\text { the frequency and validity range for calibration } \\
\text { of the temperature sensors. } 2 \text {. They are too } \\
\text { general, too broad, or not sufficiently detailed to } \\
\text { assure compliance with EPA regulatory } \\
\text { requirements. }\end{array}$ \\
\hline & & & $\begin{array}{l}\text { ASTM D3154-91 } \\
\text { (1995), "Standard } \\
\text { Method for Average } \\
\text { Velocity in a Duct } \\
\text { (Pitot Tube Method)" }\end{array}$ & $\begin{array}{l}\text { Is too general, too broad, or not sufficiently } \\
\text { detailed to assure compliance with EPA } \\
\text { regulatory requirements. }\end{array}$ \\
\hline 18 & EPA & $\begin{array}{l}\text { EPA Method 2C - } \\
\text { Velocity and Flow Rate, } \\
\text { Standard Pitot }\end{array}$ & $\begin{array}{l}\text { ASTM D3154-00, } \\
\text { Standard Method for } \\
\text { Average Velocity in a } \\
\text { Duct (Pitot Tube } \\
\text { Method) }\end{array}$ & $\begin{array}{l}\text { 1. The standard appears to lack in quality } \\
\text { control and quality assurance requirements. It } \\
\text { does not include the following: (1) Proof that } \\
\text { openings of standard pitot tube have not plugged } \\
\text { during the test; (2) if differential pressure gauges } \\
\text { other than inclined manometers (e.g., } \\
\text { magnehelic gauges) are used, their calibration } \\
\text { must be checked after each test series; and (3) } \\
\text { the frequency and validity range for calibration } \\
\text { of the temperature sensors. 2. They are too } \\
\text { general, too broad, or not sufficiently detailed to } \\
\text { assure compliance with EPA regulatory } \\
\text { requirements. }\end{array}$ \\
\hline \multirow[t]{2}{*}{19} & \multirow[t]{2}{*}{ EPA } & \multirow[t]{2}{*}{$\begin{array}{l}\text { EPA Method } 3- \\
\text { Molecular Weight Carbon } \\
\text { Dioxide, Oxygen }\end{array}$} & $\begin{array}{l}\text { ASME C00031 or PTC } \\
\text { 19-10-1981--part 10, } \\
\text { "Flue and Exhaust Gas } \\
\text { Analyses" }\end{array}$ & $\begin{array}{l}\text { Is too general, too broad, or not sufficiently } \\
\text { detailed to assure compliance with EPA } \\
\text { regulatory requirements. }\end{array}$ \\
\hline & & & $\begin{array}{l}\text { ASTM D3154-00, } \\
\text { Standard Method for } \\
\text { Average Velocity in a } \\
\text { Duct (Pitot Tube } \\
\text { Method) }\end{array}$ & $\begin{array}{l}\text { 1. The standard appears to lack in quality } \\
\text { control and quality assurance requirements. It } \\
\text { does not include the following: (1) Proof that } \\
\text { openings of standard pitot tube have not plugged } \\
\text { during the test; (2) if differential pressure gauges } \\
\text { other than inclined manometers (e.g., }\end{array}$ \\
\hline
\end{tabular}




\begin{tabular}{|c|c|c|c|c|}
\hline & Agency & $\begin{array}{c}\text { Government-Unique } \\
\text { Standard }\end{array}$ & $\begin{array}{l}\text { Voluntary } \\
\text { Consensus } \\
\text { Standard }\end{array}$ & Rationale Provided by Agency \\
\hline & & & & $\begin{array}{l}\text { magnehelic gauges) are used, their calibration } \\
\text { must be checked after each test series; and ( } 3 \text { ) } \\
\text { the frequency and validity range for calibration } \\
\text { of the temperature sensors. 2. They are too } \\
\text { general, too broad, or not sufficiently detailed to } \\
\text { assure compliance with EPA regulatory } \\
\text { requirements. }\end{array}$ \\
\hline \multirow[t]{3}{*}{20} & \multirow[t]{3}{*}{ EPA } & \multirow[t]{3}{*}{$\begin{array}{l}\text { EPA Method 3A - } \\
\text { Carbon Dioxide and } \\
\text { Oxygen Concentrations, } \\
\text { IAP }\end{array}$} & $\begin{array}{l}\text { ASTM D5835-95, } \\
\text { Standard Practice for } \\
\text { Sampling Stationary } \\
\text { Source Emissions for } \\
\text { Automated } \\
\text { Determination of Gas } \\
\text { Concentration }\end{array}$ & $\begin{array}{l}\text { 1. They lack in detail and quality } \\
\text { assurance/quality control requirements. } \\
\text { Specifically, these two standards do not include } \\
\text { the following: (1) Sensitivity of the method; } \\
\text { (2) acceptable levels of analyzer calibration } \\
\text { error; (3) acceptable levels of sampling system } \\
\text { bias; (4) zero drift and calibration drift limits, } \\
\text { time span, and required testing frequency; (5) a } \\
\text { method to test the interference response of the } \\
\text { analyzer; (6) procedures to determine the } \\
\text { minimum sampling time per run and minimum } \\
\text { measurement time; and (7) specifications for } \\
\text { data recorders, in terms of resolution (all types) } \\
\text { and recording intervals (digital and analog } \\
\text { recorders, only). 2. Is too general, too broad, or } \\
\text { not sufficiently detailed to assure compliance } \\
\text { with EPA regulatory requirements. }\end{array}$ \\
\hline & & & $\begin{array}{l}\text { CAN/CSA Z223.2- } \\
\text { M86(1986), Method for } \\
\text { the Continuous } \\
\text { Measurement of } \\
\text { Oxygen, Carbon } \\
\text { Dioxide, Carbon } \\
\text { Monoxide, Sulphur } \\
\text { Dioxide, and Oxides of } \\
\text { Nitrogen in Enclosed } \\
\text { Combustion Flue Gas } \\
\text { Stream }\end{array}$ & $\begin{array}{l}\text { 1. It does not include quantitative specifications } \\
\text { for measurement system performance, most } \\
\text { notably the calibration procedures and } \\
\text { instrument performance characteristics. The } \\
\text { instrument performance characteristics that are } \\
\text { provided are nonmandatory and also do not } \\
\text { provide the same level of quality assurance as } \\
\text { the EPA methods. For example, the zero and } \\
\text { span/calibration drift is only checked weekly, } \\
\text { whereas the EPA methods requires drift checks } \\
\text { after each run. 2. Is too general, too broad, or } \\
\text { not sufficiently detailed to assure compliance } \\
\text { with EPA regulatory requirements. }\end{array}$ \\
\hline & & & $\begin{array}{l}\text { ISO 10396:1993, } \\
\text { Stationary Source } \\
\text { Emissions: Sampling } \\
\text { for the Automated } \\
\text { Determination of Gas } \\
\text { Concentrations }\end{array}$ & $\begin{array}{l}\text { 1. They lack in detail and quality } \\
\text { assurance/quality control requirements. } \\
\text { Specifically, these two standards do not include } \\
\text { the following: (1) Sensitivity of the method; } \\
\text { (2) acceptable levels of analyzer calibration } \\
\text { error; (3) acceptable levels of sampling system } \\
\text { bias; (4) zero drift and calibration drift limits, } \\
\text { time span, and required testing frequency; (5) a } \\
\text { method to test the interference response of the } \\
\text { analyzer; (6) procedures to determine the } \\
\text { minimum sampling time per run and minimum } \\
\text { measurement time; and (7) specifications for }\end{array}$ \\
\hline
\end{tabular}




\begin{tabular}{|c|c|c|c|c|}
\hline & Agency & $\begin{array}{l}\text { Government-Unique } \\
\text { Standard }\end{array}$ & $\begin{array}{l}\text { Voluntary } \\
\text { Consensus } \\
\text { Standard }\end{array}$ & Rationale Provided by Agency \\
\hline & & & & $\begin{array}{l}\text { data recorders, in terms of resolution (all types) } \\
\text { and recording intervals (digital and analog } \\
\text { recorders, only). 2. Is too general, too broad, or } \\
\text { not sufficiently detailed to assure compliance } \\
\text { with EPA regulatory requirements. }\end{array}$ \\
\hline & & & $\begin{array}{l}\text { ISO 12039:2001, } \\
\text { Stationary Source } \\
\text { Emissions-- } \\
\text { Determination of } \\
\text { Carbon Monoxide, } \\
\text { Carbon Dioxide, and } \\
\text { Oxygen--Automated } \\
\text { Methods }\end{array}$ & $\begin{array}{l}\text { This ISO standard is similar to EPA Method 3A, } \\
\text { but is missing some key features. In terms of } \\
\text { sampling, the hardware required by ISO } \\
\text { 12039:2001 does not include a 3-way calibration } \\
\text { valve assembly or equivalent to block the sample } \\
\text { gas flow while calibration gases are introduced. } \\
\text { In its calibration procedures, ISO 12039:2001 } \\
\text { only specifies a two-point calibration while EPA } \\
\text { Method 3A specifies a three-point calibration. } \\
\text { Also, ISO 12039:2001 does not specify } \\
\text { performance criteria for calibration error, } \\
\text { calibration drift, or sampling system bias tests as } \\
\text { in the EPA method, although checks of these } \\
\text { quality control features are required by the ISO } \\
\text { standard. }\end{array}$ \\
\hline \multirow[t]{2}{*}{21} & \multirow[t]{2}{*}{ EPA } & \multirow[t]{2}{*}{$\begin{array}{l}\text { Method 3B - Oxygen, } \\
\text { Carbon Dioxide, Carbon } \\
\text { Monoxide, Emission Rate } \\
\text { Correction Factor }\end{array}$} & $\begin{array}{l}\text { ASTM D3154-00, } \\
\text { Standard Method for } \\
\text { Average Velocity in a } \\
\text { Duct (Pitot Tube } \\
\text { Method) }\end{array}$ & $\begin{array}{l}\text { 1. The standard appears to lack in quality } \\
\text { control and quality assurance requirements. It } \\
\text { does not include the following: (1) Proof that } \\
\text { openings of standard pitot tube have not plugged } \\
\text { during the test; (2) if differential pressure gauges } \\
\text { other than inclined manometers (e.g., } \\
\text { magnehelic gauges) are used, their calibration } \\
\text { must be checked after each test series; and (3) } \\
\text { the frequency and validity range for calibration } \\
\text { of the temperature sensors. 2. They are too } \\
\text { general, too broad, or not sufficiently detailed to } \\
\text { assure compliance with EPA regulatory } \\
\text { requirements. }\end{array}$ \\
\hline & & & $\begin{array}{l}\text { ASTM D3154-91 } \\
\text { (1995), "Standard } \\
\text { Method for Average } \\
\text { Velocity in a Duct } \\
\text { (Pitot Tube Method)" }\end{array}$ & $\begin{array}{l}\text { Is too general, too broad, or not sufficiently } \\
\text { detailed to assure compliance with EPA } \\
\text { regulatory requirements. }\end{array}$ \\
\hline \multirow[t]{2}{*}{22} & \multirow[t]{2}{*}{ EPA } & \multirow[t]{2}{*}{$\begin{array}{l}\text { EPA Method } 4-\text { Moisture } \\
\text { Content in Stack Gases }\end{array}$} & $\begin{array}{l}\text { ASTM E337-84 } \\
\text { (1996), "Standard Test } \\
\text { Method for Measuring } \\
\text { Humidity with a } \\
\text { Psychrometer (the } \\
\text { Measurement of Wet- } \\
\text { and Dry-Bulb } \\
\text { Temperatures)" }\end{array}$ & $\begin{array}{l}\text { They are too general, too broad, or not } \\
\text { sufficiently detailed to assure compliance with } \\
\text { EPA regulatory requirements. }\end{array}$ \\
\hline & & & $\begin{array}{l}\text { ASTM D3154-00, } \\
\text { Standard Method for }\end{array}$ & $\begin{array}{l}\text { 1. The standard appears to lack in quality } \\
\text { control and quality assurance requirements. It }\end{array}$ \\
\hline
\end{tabular}




\begin{tabular}{|c|c|c|c|c|}
\hline & Agency & $\begin{array}{l}\text { Government-Unique } \\
\text { Standard }\end{array}$ & $\begin{array}{l}\text { Voluntary } \\
\text { Consensus } \\
\text { Standard }\end{array}$ & Rationale Provided by Agency \\
\hline & & & $\begin{array}{l}\text { Average Velocity in a } \\
\text { Duct (Pitot Tube } \\
\text { Method) }\end{array}$ & $\begin{array}{l}\text { does not include the following: (1) Proof that } \\
\text { openings of standard pitot tube have not plugged } \\
\text { during the test; (2) if differential pressure gauges } \\
\text { other than inclined manometers } \\
\text { (e.g., magnehelic gauges) are used, their } \\
\text { calibration must be checked after each test } \\
\text { series; and (3) the frequency and validity range } \\
\text { for calibration of the temperature sensors. } \\
\text { 2. They are too general, too broad, or not } \\
\text { sufficiently detailed to assure compliance with } \\
\text { EPA regulatory requirements. }\end{array}$ \\
\hline & & & $\begin{array}{l}\text { ASTM D3154-91 } \\
\text { (1995), "Standard } \\
\text { Method for Average } \\
\text { Velocity in a Duct } \\
\text { (Pitot Tube Method)" }\end{array}$ & $\begin{array}{l}\text { Is too general, too broad, or not sufficiently } \\
\text { detailed to assure compliance with EPA } \\
\text { regulatory requirements. }\end{array}$ \\
\hline \multirow[t]{3}{*}{23} & \multirow[t]{3}{*}{ EPA } & \multirow[t]{3}{*}{$\begin{array}{l}\text { EPA Method } 5- \\
\text { Particulate Matter, } \\
\text { Stationary Sources }\end{array}$} & $\begin{array}{l}\text { ASME PTC-38-80 R85 } \\
\text { or C00049, } \\
\text { "Determination of the } \\
\text { Concentration of } \\
\text { Particulate Matter in } \\
\text { Gas Streams" }\end{array}$ & $\begin{array}{l}\text { It lacks sufficient quality assurance and quality } \\
\text { control requirements necessary for EPA } \\
\text { compliance assurance requirements. }\end{array}$ \\
\hline & & & $\begin{array}{l}\text { ASTM } \\
\text { D3685/D3685M-98, } \\
\text { “Test Methods for } \\
\text { Sampling and } \\
\text { Determination of } \\
\text { Particulate Matter in } \\
\text { Stack Gases.” }\end{array}$ & $\begin{array}{l}\text { It lacks sufficient quality assurance and quality } \\
\text { control requirements necessary for EPA } \\
\text { compliance assurance requirements. }\end{array}$ \\
\hline & & & $\begin{array}{l}\text { ISO 9096:1992, } \\
\text { "Determination of } \\
\text { Concentration and } \\
\text { Mass Flow Rate of } \\
\text { Particulate Matter in } \\
\text { Gas Carrying Ducts-- } \\
\text { Manual Gravimetric } \\
\text { Method" }\end{array}$ & $\begin{array}{l}\text { It lacks sufficient quality assurance and quality } \\
\text { control requirements necessary for EPA } \\
\text { compliance assurance requirements. }\end{array}$ \\
\hline 24 & EPA & $\begin{array}{l}\text { EPA Method } 5 \text { i - Low } \\
\text { Level Particulate Matter, } \\
\text { Stationary Sources }\end{array}$ & ASTM D6331-98 & $\begin{array}{l}\text { This standard does not have paired trains as } \\
\text { specified in method } 5 \text { and does not include some } \\
\text { quality control procedures specified in the EPA } \\
\text { method and which are appropriate to use in this } \\
\text { rule. }\end{array}$ \\
\hline \multirow[t]{2}{*}{25} & \multirow[t]{2}{*}{ EPA } & \multirow[t]{2}{*}{$\begin{array}{l}\text { EPA Method } 6 \text { - Sulphur } \\
\text { Dioxide Emissions }\end{array}$} & $\begin{array}{l}\text { ASME C00031 or PTC } \\
\text { 19-10-1981 - Part } 10 \\
\text { Flue and Exhaust Gas } \\
\text { Analyses }\end{array}$ & $\begin{array}{l}\text { Too broad to be useful in regulatory sense. } \\
\text { Covers Methods 3, 6, 7, and } 15 \text { with variants. }\end{array}$ \\
\hline & & & $\begin{array}{l}\text { ISO 7934:1998 - } \\
\text { Stationary Source } \\
\text { Emissions - }\end{array}$ & $\begin{array}{l}\text { This standard is only applicable to sources with } \\
30 \mathrm{mg} / \mathrm{m} 3 \mathrm{SO} 2 \text { or more. In addition, this } \\
\text { method does not separate SO3 from SO2 as does }\end{array}$ \\
\hline
\end{tabular}




\begin{tabular}{|c|c|c|c|c|}
\hline & Agency & $\begin{array}{l}\text { Government-Unique } \\
\text { Standard }\end{array}$ & $\begin{array}{c}\text { Voluntary } \\
\text { Consensus } \\
\text { Standard }\end{array}$ & Rationale Provided by Agency \\
\hline & & & $\begin{array}{l}\text { Determination of the } \\
\text { Mass Concentration of } \\
\text { Sulfur Dioxide - } \\
\text { Hydrogen } \\
\text { Peroxide/Barium } \\
\text { Perchlorate/ Thorin } \\
\text { Method }\end{array}$ & $\begin{array}{l}\text { EPA Method 6; therefore, this method is not } \\
\text { valid if more than a negligible amount of SO3 is } \\
\text { present. Also, does not address ammonia } \\
\text { interferences. }\end{array}$ \\
\hline & & & $\begin{array}{l}\text { ISO 11632:1998 - } \\
\text { Stationary Source } \\
\text { Emissions - } \\
\text { Determination of the } \\
\text { Mass Concentration of } \\
\text { Sulfur Dioxide - Ion } \\
\text { Chromatography }\end{array}$ & $\begin{array}{l}\text { ISO 11632:1998 - Stationary Source Emissions - } \\
\text { Determination of the Mass Concentration of } \\
\text { Sulfur Dioxide - Ion Chromatography } \\
\text { (NIST HAS A CALL IN TO EPA } \\
\text { REGARDING THIS BOX) }\end{array}$ \\
\hline \multirow[t]{3}{*}{26} & \multirow[t]{3}{*}{ EPA } & \multirow[t]{3}{*}{$\begin{array}{l}\text { EPA Method } 6 c-\text { Sulphur } \\
\text { Dioxide Emissions, } \\
\text { Stationary by IAP }\end{array}$} & $\begin{array}{l}\text { ISO 10396:1993 - } \\
\text { Stationary Source } \\
\text { Emissions: Sampling } \\
\text { for the Automated } \\
\text { Determination of Gas } \\
\text { Concentrations }\end{array}$ & $\begin{array}{l}\text { Duplicates Methods 3a, 6c, 7e, 10, ALT } 004 \text { and } \\
\text { CTM } 022 \text {. Lacks in detail and quality assurance } \\
\text { plus quality control requirements. Similar to } \\
\text { ASTM D5835. }\end{array}$ \\
\hline & & & $\begin{array}{l}\text { ASTM D5835-95 - } \\
\text { Standard Practice for } \\
\text { Sampling Stationary } \\
\text { Source Emissions for } \\
\text { Automated } \\
\text { Determination of Gas } \\
\text { Concentration. }\end{array}$ & $\begin{array}{l}\text { Similar to Methods 3a, 6c, 7e, 10, ALT } 004 \text { and } \\
\text { CTM 022. Lacks in detail and quality assurance } \\
\text { and quality control requirements. Very similar } \\
\text { to ISO } 10396 .\end{array}$ \\
\hline & & & $\begin{array}{l}\text { CAN/CSA Z223.2- } \\
\text { M86 - (1986) Method } \\
\text { for the Continuous } \\
\text { Measurement of } \\
\text { Oxygen, Carbon } \\
\text { Doixide, Carbon } \\
\text { Monoxide, Sulphur } \\
\text { Dioxide, and Oxides of } \\
\text { Nitrogen in Enclosed } \\
\text { Combustion Flue Gas } \\
\text { Streams }\end{array}$ & $\begin{array}{l}\text { Too general. This standard lacks in detail and } \\
\text { quality assurance/quality control requirements. } \\
\text { Appendices with valid quality control } \\
\text { information are not a required }\end{array}$ \\
\hline 27 & EPA & $\begin{array}{l}\text { EPA Method } 7 \text { - Nitrogen } \\
\text { Oxide Emissions, } \\
\text { Stationary Sources }\end{array}$ & $\begin{array}{l}\text { ASME C00031 or PTC } \\
19-10-1981 \text { - Part } 10 \\
\text { Flue and Exhaust Gas } \\
\text { Analyses }\end{array}$ & $\begin{array}{l}\text { Too broad to be useful in regulatory sense. } \\
\text { Covers Methods 3, 6, 7, and } 15 \text { with variants. }\end{array}$ \\
\hline \multirow[t]{2}{*}{28} & \multirow[t]{2}{*}{ EPA } & \multirow[t]{2}{*}{$\begin{array}{l}\text { EPA Method 7e- } \\
\text { Nitrogen Oxide, } \\
\text { Instrumental }\end{array}$} & $\begin{array}{l}\text { ISO 10396:1993 - } \\
\text { Stationary Source } \\
\text { Emissions: Sampling } \\
\text { for the Automated } \\
\text { Determination of Gas } \\
\text { Concentrations }\end{array}$ & $\begin{array}{l}\text { Duplicates Methods 3a, 6c, 7e, 10, ALT } 004 \text { and } \\
\text { CTM 022. Lacks in detail and quality assurance } \\
\text { plus quality control requirements. Similar to } \\
\text { ASTM D5835. }\end{array}$ \\
\hline & & & ASTM D5835-95 - & Similar to Methods 3a, 6c, 7e, 10, ALT 004 and \\
\hline
\end{tabular}




\begin{tabular}{|c|c|c|c|c|}
\hline & Agency & $\begin{array}{c}\text { Government-Unique } \\
\text { Standard }\end{array}$ & $\begin{array}{l}\text { Voluntary } \\
\text { Consensus } \\
\text { Standard }\end{array}$ & Rationale Provided by Agency \\
\hline & & & $\begin{array}{l}\text { Standard Practice for } \\
\text { Sampling Stationary } \\
\text { Source Emissions for } \\
\text { Automated } \\
\text { Determination of Gas } \\
\text { Concentration. }\end{array}$ & $\begin{array}{l}\text { CTM 022. Lacks in detail and quality assurance } \\
\text { and quality control requirements. Very similar } \\
\text { to ISO } 10396 .\end{array}$ \\
\hline & & & $\begin{array}{l}\text { CAN/CSA Z223.2- } \\
\text { M86 - (1986) Method } \\
\text { for the Continuous } \\
\text { Measurement of } \\
\text { Oxygen, Carbon } \\
\text { Doixide, Carbon } \\
\text { Monoxide, Sulphur } \\
\text { Dioxide, and Oxides of } \\
\text { Nitrogen in Enclosed } \\
\text { Combustion Flue Gas } \\
\text { Streams }\end{array}$ & $\begin{array}{l}\text { Too general. This standard lacks in detail and } \\
\text { quality assurance/quality control requirements. } \\
\text { Appendices with valid quality control } \\
\text { information are not a required part of this } \\
\text { method. }\end{array}$ \\
\hline \multirow[t]{2}{*}{29} & \multirow[t]{2}{*}{ EPA } & \multirow[t]{2}{*}{$\begin{array}{l}\text { EPA Method } 10 \text { - Carbon } \\
\text { Monoxide, NDIR }\end{array}$} & $\begin{array}{l}\text { ASTM D3162 (1994) } \\
\text { Standard Test Method } \\
\text { for Carbon Monoxide } \\
\text { in the Atmosphere } \\
\text { (Continuous } \\
\text { Measurement by Non- } \\
\text { dispersive Infrared } \\
\text { Spectrometry) }\end{array}$ & $\begin{array}{l}\text { This ASTM standard, which is stated to be } \\
\text { applicable in the range of } 0.5-100 \text { ppm CO, does } \\
\text { not cover the range of EPA Method } 10 \text { ( } 20-1,000 \\
\text { ppm CO) at the upper end (but states that it has a } \\
\text { lower limit of sensitivity). Also, ASTM D3162 } \\
\text { does not provide a procedure to remove carbon } \\
\text { dioxide interference. Therefore, this ASTM } \\
\text { standard is not appropriate for combustion } \\
\text { source conditions. In terms of non-dispersive } \\
\text { infrared instrument performance specifications, } \\
\text { ASTM D3162 has much higher maximum } \\
\text { allowable rise and fall times ( } 5 \text { minutes) than } \\
\text { EPA Method } 10 \text { (which has } 30 \text { seconds). }\end{array}$ \\
\hline & & & $\begin{array}{l}\text { CAN/CSA Z223.21- } \\
\text { M1978, Method for the } \\
\text { Measurement of } \\
\text { Carbon Monoxide: 3- } \\
\text { Method of Analysis by } \\
\text { Non-Dispersive } \\
\text { Infrared Spectrometry. }\end{array}$ & $\begin{array}{l}\text { 1. It is lacking in the following areas: (1) } \\
\text { Sampling procedures; (2) procedures to correct } \\
\text { for the carbon dioxide concentration; } \\
\text { (3) instructions to correct the gas volume if CO2 } \\
\text { traps are used; (4) specifications to certify the } \\
\text { calibration gases are within } 2 \text { percent of the } \\
\text { target concentration; (5) mandatory instrument } \\
\text { performance characteristics (e.g., rise time, fall } \\
\text { time, zero drift, span drift, and precision); } \\
\text { (6) quantitative specification of the span value } \\
\text { maximum as compared to the measured value: } \\
\text { The standard specifies that the instruments } \\
\text { should be compatible with the concentration of } \\
\text { gases to be measured, whereas EPA Method } 10 \\
\text { specifies that the instrument span value should } \\
\text { be no more than } 1.5 \text { times the source } \\
\text { performance standard. } 2 \text {. Is too general, too } \\
\text { broad, or not sufficiently detailed to assure } \\
\text { compliance with EPA regulatory requirements. }\end{array}$ \\
\hline 30 & EPA & EPA Method 10A - & CAN/CSA Z223.21- & 1. It is lacking in the following areas: (1) \\
\hline
\end{tabular}




\begin{tabular}{|c|c|c|c|c|}
\hline & Agency & $\begin{array}{l}\text { Government-Unique } \\
\text { Standard }\end{array}$ & $\begin{array}{c}\text { Voluntary } \\
\text { Consensus } \\
\text { Standard }\end{array}$ & Rationale Provided by Agency \\
\hline & & $\begin{array}{l}\text { Carbon Monoxide for } \\
\text { Certifying CEMS }\end{array}$ & $\begin{array}{l}\text { M1978, Method for the } \\
\text { Measurement of } \\
\text { Carbon Monoxide: 3- } \\
\text { Method of Analysis by } \\
\text { Non-Dispersive } \\
\text { Infrared Spectrometry. }\end{array}$ & $\begin{array}{l}\text { Sampling procedures; (2) procedures to correct } \\
\text { for the carbon dioxide concentration; } \\
\text { (3) instructions to correct the gas volume if CO2 } \\
\text { traps are used; (4) specifications to certify the } \\
\text { calibration gases are within } 2 \text { percent of the } \\
\text { target concentration; (5) mandatory instrument } \\
\text { performance characteristics (e.g., rise time, fall } \\
\text { time, zero drift, span drift, and precision); } \\
\text { (6) quantitative specification of the span value } \\
\text { maximum as compared to the measured value: } \\
\text { The standard specifies that the instruments } \\
\text { should be compatible with the concentration of } \\
\text { gases to be measured, whereas EPA Method } 10 \\
\text { specifies that the instrument span value should } \\
\text { be no more than } 1.5 \text { times the source } \\
\text { performance standard. 2. Is too general, too } \\
\text { broad, or not sufficiently detailed to assure } \\
\text { compliance with EPA regulatory requirements. }\end{array}$ \\
\hline \multirow[t]{2}{*}{31} & \multirow[t]{2}{*}{ EPA } & \multirow[t]{2}{*}{$\begin{array}{l}\text { EPA Method } 12- \\
\text { Inorganic Lead, } \\
\text { Stationary Sources }\end{array}$} & $\begin{array}{l}\text { ASTM D4358-94 } \\
\text { (1999), "Standard Test } \\
\text { Method for Lead and } \\
\text { Chromium in Air } \\
\text { Particulate Filter } \\
\text { Samples of Lead } \\
\text { Chromate Type } \\
\text { Pigment Dusts by } \\
\text { Atomic Absorption } \\
\text { Spectroscopy" }\end{array}$ & $\begin{array}{l}\text { These ASTM standards do not require the use of } \\
\text { glass fiber filters as in EPA Method } 12 \text { and } \\
\text { require the use of significantly different } \\
\text { digestion procedures that appear to be milder } \\
\text { than the EPA Method } 12 \text { digestion procedure. } \\
\text { For these reasons, these ASTM standards cannot } \\
\text { be considered equivalent to EPA Method } 12 \text {. } \\
\text { Also, the subject ASTM standards do not require } \\
\text { the use of hydrogen fluoride (HF) as in EPA } \\
\text { Method } 29 \text { and, therefore, they cannot be used } \\
\text { for the preparation, digestion, and analysis of } \\
\text { Method } 29 \text { samples. Additionally, Method } 29 \\
\text { requires the use of a glass fiber filter, whereas } \\
\text { these three ASTM standards require cellulose } \\
\text { filters and other probable nonglass fiber media, } \\
\text { which cannot be considered equivalent to EPA } \\
\text { Method } 29 \text {. }\end{array}$ \\
\hline & & & $\begin{array}{l}\text { ASTM E1741-95 } \\
\text { (1995), "Standard } \\
\text { Practice for Preparation } \\
\text { of Airborne Particulate } \\
\text { Lead Samples } \\
\text { Collected During } \\
\text { Abatement and } \\
\text { Construction Activities } \\
\text { for Subsequent } \\
\text { Analysis by Atomic } \\
\text { Spectrometry" }\end{array}$ & $\begin{array}{l}\text { These ASTM standards do not require the use of } \\
\text { glass fiber filters as in EPA Method } 12 \text { and } \\
\text { require the use of significantly different } \\
\text { digestion procedures that appear to be milder } \\
\text { than the EPA Method } 12 \text { digestion procedure. } \\
\text { For these reasons, these ASTM standards cannot } \\
\text { be considered equivalent to EPA Method } 12 \text {. } \\
\text { Also, the subject ASTM standards do not require } \\
\text { the use of hydrogen fluoride (HF) as in EPA } \\
\text { Method } 29 \text { and, therefore, they cannot be used } \\
\text { for the preparation, digestion, and analysis of } \\
\text { Method } 29 \text { samples. Additionally, Method } 29 \\
\text { requires the use of a glass fiber filter, whereas } \\
\text { these three ASTM standards require cellulose } \\
\text { filters and other probable nonglass fiber media, }\end{array}$ \\
\hline
\end{tabular}




\begin{tabular}{|c|c|c|c|c|}
\hline & Agency & $\begin{array}{l}\text { Government-Unique } \\
\text { Standard }\end{array}$ & $\begin{array}{c}\text { Voluntary } \\
\text { Consensus } \\
\text { Standard } \\
\end{array}$ & Rationale Provided by Agency \\
\hline & & & & $\begin{array}{l}\text { which cannot be considered equivalent to EPA } \\
\text { Method } 29 \text {. }\end{array}$ \\
\hline & & & $\begin{array}{l}\text { ASTM E1979-98 } \\
\text { (1998), "Standard } \\
\text { Practice for Ultrasonic } \\
\text { Extraction of Paint, } \\
\text { Dust, Soil, and Air } \\
\text { Samples for } \\
\text { Subsequent } \\
\text { Determination of Lead" }\end{array}$ & $\begin{array}{l}\text { These ASTM standards do not require the use of } \\
\text { glass fiber filters as in EPA Method } 12 \text { and } \\
\text { require the use of significantly different } \\
\text { digestion procedures that appear to be milder } \\
\text { than the EPA Method } 12 \text { digestion procedure. } \\
\text { For these reasons, these ASTM standards cannot } \\
\text { be considered equivalent to EPA Method } 12 \text {. } \\
\text { Also, the subject ASTM standards do not require } \\
\text { the use of hydrogen fluoride (HF) as in EPA } \\
\text { Method } 29 \text { and, therefore, they cannot be used } \\
\text { for the preparation, digestion, and analysis of } \\
\text { Method } 29 \text { samples. Additionally, Method } 29 \\
\text { requires the use of a glass fiber filter, whereas } \\
\text { these three ASTM standards require cellulose } \\
\text { filters and other probable nonglass fiber media, } \\
\text { which cannot be considered equivalent to EPA } \\
\text { Method } 29 \text {. }\end{array}$ \\
\hline \multirow[t]{2}{*}{32} & \multirow[t]{2}{*}{ EPA } & \multirow[t]{2}{*}{$\begin{array}{l}\text { EPA Method } 15- \\
\text { Hydrogen Sulfide/Carbon } \\
\text { Disulfide/Carbon Sulfide }\end{array}$} & $\begin{array}{l}\text { ASME C00031 or PTC } \\
\text { 19-10-1981 - Part } 10 \\
\text { Flue and Exhaust Gas } \\
\text { Analyses }\end{array}$ & $\begin{array}{l}\text { Too broad to be useful in regulatory sense. } \\
\text { Covers Methods 3, 6, 7, and } 15 \text { with variants. }\end{array}$ \\
\hline & & & $\begin{array}{l}\text { ASTM D4323-84 } \\
\text { (1997) - Standard Test } \\
\text { Method for Hydrogen } \\
\text { Sulfide in the } \\
\text { Atmosphere by Rate of } \\
\text { Change of Reflectance }\end{array}$ & $\begin{array}{l}\text { ASTM D4323 only applies to concentrations of } \\
\text { H2S from } 1 \mathrm{ppb} \text { to } 3 \mathrm{ppm} \text { without dilution. } \\
\text { Many QC items are missing, such as calibration } \\
\text { drift and sample line losses. The calibration } \\
\text { curve is determined with only one point. }\end{array}$ \\
\hline \multirow[t]{2}{*}{33} & \multirow[t]{2}{*}{ EPA } & \multirow[t]{2}{*}{$\begin{array}{l}\text { EPA Method } 17- \\
\text { Particulate Matter (PM), } \\
\text { In Stack Filtration }\end{array}$} & $\begin{array}{l}\text { ASTM D3685/3685M- } \\
95 \text { - Standard Test } \\
\text { Method for Sampling } \\
\text { and Determination of } \\
\text { Particulate Matter in } \\
\text { Stack Gases }\end{array}$ & $\begin{array}{l}\text { EPA looked at this standard for both Pulp and } \\
\text { Paper Hazardous Air Pollutant rules and for the } \\
\text { Small Municipal Waste Combustion rule. } \\
\text { Contains sampling options beyond which would } \\
\text { be considered acceptable for Method } 5 .\end{array}$ \\
\hline & & & ASME C00049 & $\begin{array}{l}\text { EPA looked at this standard for both Pulp and } \\
\text { Paper Hazardous Air Pollutant rules and for the } \\
\text { Small Municipal Waste Combustion rule. Too } \\
\text { flexible in allowing for more train configurations } \\
\text { than is appropriate for purposes of this rule. }\end{array}$ \\
\hline 34 & EPA & $\begin{array}{l}\text { EPA Method } 18- \\
\text { VOC/GC }\end{array}$ & $\begin{array}{l}\text { ASTM D6060-96 (in } \\
\text { review 2000) - Practice } \\
\text { for Sampling of } \\
\text { Process Vents with a } \\
\text { Portable Gas } \\
\text { Chromatography }\end{array}$ & $\begin{array}{l}\text { This standard lacks key quality control and } \\
\text { assurance that is required for EPA Method } 18 . \\
\text { For example: lacks acceptance criteria for } \\
\text { calibration, details on using other collection } \\
\text { media (e.g. solid sorbents), and reporting/ } \\
\text { documentation requirements. }\end{array}$ \\
\hline $\begin{array}{l}35 \\
*\end{array}$ & EPA & $\begin{array}{l}\text { EPA Method 21 - } \\
\text { Volatile Organic } \\
\text { Compound (VOC) Leaks }\end{array}$ & $\begin{array}{l}\text { ASTM E1211-97 - } \\
\text { Standard Practice for } \\
\text { Leak Detection and } \\
\text { Location Using } \\
\text { Surface-Mounted } \\
\end{array}$ & $\begin{array}{l}\text { This standard will detect leaks but not "classify" } \\
\text { the leak as VOC, as in EPA Method 21. In } \\
\text { addition, in order to detect the VOC } \\
\text { concentration of a known VOC leak, the } \\
\text { acoustic signal would need to be calibrated }\end{array}$ \\
\hline
\end{tabular}




\begin{tabular}{|c|c|c|c|c|}
\hline & Agency & $\begin{array}{l}\text { Government-Unique } \\
\text { Standard }\end{array}$ & $\begin{array}{l}\text { Voluntary } \\
\text { Consensus } \\
\text { Standard }\end{array}$ & Rationale Provided by Agency \\
\hline & & & $\begin{array}{l}\text { Acoustic Emission } \\
\text { Sensors }\end{array}$ & $\begin{array}{l}\text { against a primary instrument. Background noise } \\
\text { interference in some source situations could also } \\
\text { make this standard difficult to use effectively. }\end{array}$ \\
\hline 36 & EPA & $\begin{array}{l}\text { EPA Method } 23-\text { Dioxin } \\
\text { and Furan (PCDD and } \\
\text { PCDF) }\end{array}$ & $\begin{array}{l}\text { European Committee } \\
\text { for Standardization } \\
\text { (CEN) EN 1948-3 } \\
\text { (1997), "Determination } \\
\text { of the Mass } \\
\text { Concentration of } \\
\text { PCDD'S/PCDF'S--Part } \\
\text { 3: Identification and } \\
\text { Quantification" }\end{array}$ & $\begin{array}{l}\text { Upper and lower detection limits do not support } \\
\text { regulatory levels specified in Rule \# } 68 \text { FR } \\
\text { 5144-01, } 2003 \text { (WL 201268) "Federal Plan } \\
\text { Requirements for Small Municipal Waste } \\
\text { Combustion Units Constructed On or Before } \\
\text { August 30, 1999." }\end{array}$ \\
\hline \multirow[t]{2}{*}{37} & \multirow[t]{2}{*}{ EPA } & \multirow[t]{2}{*}{$\begin{array}{l}\text { EPA Method } 24 \text { - Surface } \\
\text { Coatings, Volatile Matter } \\
\text { Content }\end{array}$} & $\begin{array}{l}\text { ISO 11890-1 (2000) } \\
\text { part 1, "Paints and } \\
\text { Varnishes-- } \\
\text { Determination of } \\
\text { Volatile Organic } \\
\text { Compound (VOC) } \\
\text { Content-Difference } \\
\text { Method" }\end{array}$ & $\begin{array}{l}\text { Measured nonvolatile matter content can vary } \\
\text { with experimental factors such as temperature, } \\
\text { length of heating period, size of weighing dish, } \\
\text { and size of sample. The standard ISO } 11890-1 \\
\text { allows for different dish weights and sample } \\
\text { sizes than the one size ( } 58 \text { millimeters in } \\
\text { diameter and sample size of } 0.5 \text { gram) of EPA } \\
\text { Method } 24 \text {. The standard ISO } 11890-1 \text { also } \\
\text { allows for different oven temperatures and } \\
\text { heating times depending on the type of coating, } \\
\text { whereas EPA Method } 24 \text { requires } 60 \text { minutes } \\
\text { heating at } 110 \text { degrees Celcius at all times. } \\
\text { Because the EPA Method } 24 \text { test conditions and } \\
\text { procedures "define" volatile matter, ISO } 11890-1 \\
\text { is unacceptable as an alternative because of its } \\
\text { different test conditions. }\end{array}$ \\
\hline & & & $\begin{array}{l}\text { ISO 11890-2 (2000) } \\
\text { part 2, "Paints and } \\
\text { Varnishes-- } \\
\text { Determination of } \\
\text { Volatile Organic } \\
\text { Compound (VOC) } \\
\text { Content-Gas } \\
\text { Chromatographic } \\
\text { Method" }\end{array}$ & $\begin{array}{l}\text { ISO } 11890-2 \text { only measures the VOC added to } \\
\text { the coating and would not measure any VOC } \\
\text { generated from the curing of the coating. The } \\
\text { EPA Method } 24 \text { does measure "cure" VOC, } \\
\text { which can be significant in some cases, and, } \\
\text { therefore, ISO 11890-2 is not an acceptable } \\
\text { alternative to this EPA method. }\end{array}$ \\
\hline \multirow[t]{2}{*}{38} & \multirow[t]{2}{*}{ EPA } & \multirow[t]{2}{*}{$\begin{array}{l}\text { EPA Method } 25- \\
\text { Gaseous Nonmethane } \\
\text { Organic Emissions }\end{array}$} & $\begin{array}{l}\text { EN 12619:1999 } \\
\text { Stationary Source } \\
\text { Emissions-- } \\
\text { Determination of the } \\
\text { Mass Concentration of } \\
\text { Total Gaseous Organic } \\
\text { Carbon at Low } \\
\text { Concentrations in Flue } \\
\text { Gases--Continuous } \\
\text { Flame Ionization } \\
\text { Detector Method }\end{array}$ & $\begin{array}{l}\text { The standards do not apply to solvent process } \\
\text { vapors in concentrations greater than } 40 \mathrm{ppm} \\
\text { (EN 12619) and } 10 \mathrm{ppm} \text { carbon (ISO 14965). } \\
\text { Methods whose upper limits are this low are too } \\
\text { limited to be useful in measuring source } \\
\text { emissions, which are expected to be much } \\
\text { higher. }\end{array}$ \\
\hline & & & $\begin{array}{l}\text { ISO 14965:2000(E) Air } \\
\text { Quality--Determination }\end{array}$ & $\begin{array}{l}\text { The standards do not apply to solvent process } \\
\text { vapors in concentrations greater than } 40 \mathrm{ppm}\end{array}$ \\
\hline
\end{tabular}




\begin{tabular}{|c|c|c|c|c|}
\hline & Agency & $\begin{array}{c}\text { Government-Unique } \\
\text { Standard }\end{array}$ & $\begin{array}{c}\text { Voluntary } \\
\text { Consensus } \\
\text { Standard }\end{array}$ & Rationale Provided by Agency \\
\hline & & & $\begin{array}{l}\text { of Total Nonmethane } \\
\text { Organic Compounds-- } \\
\text { Cryogenic } \\
\text { Preconcentration and } \\
\text { Direct Flame Ionization } \\
\text { Method }\end{array}$ & $\begin{array}{l}\text { (EN 12619) and } 10 \text { ppm carbon (ISO 14965). } \\
\text { Methods whose upper limits are this low are too } \\
\text { limited to be useful in measuring source } \\
\text { emissions, which are expected to be much } \\
\text { higher. }\end{array}$ \\
\hline \multirow[t]{2}{*}{39} & EPA & $\begin{array}{l}\text { EPA Method 25A - } \\
\text { Gaseous Organic } \\
\text { Concentration, Flame } \\
\text { Ionization }\end{array}$ & $\begin{array}{l}\text { EN 12619:1999 } \\
\text { Stationary Source } \\
\text { Emissions-- } \\
\text { Determination of the } \\
\text { Mass Concentration of } \\
\text { Total Gaseous Organic } \\
\text { Carbon at Low } \\
\text { Concentrations in Flue } \\
\text { Gases--Continuous } \\
\text { Flame Ionization } \\
\text { Detector Method }\end{array}$ & $\begin{array}{l}\text { The standards do not apply to solvent process } \\
\text { vapors in concentrations greater than } 40 \mathrm{ppm} \\
\text { (EN 12619) and } 10 \mathrm{ppm} \text { carbon (ISO 14965). } \\
\text { Methods whose upper limits are this low are too } \\
\text { limited to be useful in measuring source } \\
\text { emissions, which are expected to be much } \\
\text { higher. }\end{array}$ \\
\hline & & & $\begin{array}{l}\text { ISO 14965:2000(E) Air } \\
\text { Quality--Determination } \\
\text { of Total Nonmethane } \\
\text { Organic Compounds-- } \\
\text { Cryogenic } \\
\text { Preconcentration and } \\
\text { Direct Flame Ionization } \\
\text { Method }\end{array}$ & $\begin{array}{l}\text { The standards do not apply to solvent process } \\
\text { vapors in concentrations greater than } 40 \text { ppm } \\
\text { (EN 12619) and } 10 \text { ppm carbon (ISO 14965). } \\
\text { Methods whose upper limits are this low are too } \\
\text { limited to be useful in measuring source } \\
\text { emissions, which are expected to be much } \\
\text { higher. }\end{array}$ \\
\hline 40 & EPA & $\begin{array}{l}\text { EPA Method } 26- \\
\text { Hydrogen Chloride, } \\
\text { Halides, Halogens } \\
\text { Emissions }\end{array}$ & $\begin{array}{l}\text { EN 1911-1,2,3 (1998), } \\
\text { "Stationary Source } \\
\text { Emissions-- Manual } \\
\text { Method of } \\
\text { Determination of HCl-- } \\
\text { Part 1: Sampling of } \\
\text { Gases Ratified } \\
\text { European Text--Part 2: } \\
\text { Gaseous Compounds } \\
\text { Absorption Ratified } \\
\text { European Text-- Part 3: } \\
\text { Adsorption Solutions } \\
\text { Analysis and } \\
\text { Calculation Ratified } \\
\text { European Text" }\end{array}$ & $\begin{array}{l}\text { Part } 3 \text { of this standard cannot be considered } \\
\text { equivalent to EPA Method } 26 \text { or 26A because } \\
\text { the sample absorbing solution (water) would be } \\
\text { expected to capture both HCl and Cl2 gas, if } \\
\text { present, without the ability to distinguish } \\
\text { between the two. The EPA Methods } 26 \text { and 26A } \\
\text { use an acidified absorbing solution to first } \\
\text { separate } \mathrm{HCl} \text { and } \mathrm{Cl} 2 \text { gas so that they can be } \\
\text { selectively absorbed, analyzed, and reported } \\
\text { separately. In addition, in EN } 1911 \text { the } \\
\text { absorption efficiency for Cl2 gas would be } \\
\text { expected to vary as the pH of the water changed } \\
\text { during sampling. }\end{array}$ \\
\hline 41 & EPA & $\begin{array}{l}\text { EPA Method 26A - } \\
\text { Hydrogen Halide and } \\
\text { Halogen, Isokinetic }\end{array}$ & $\begin{array}{l}\text { EN 1911-1,2,3 (1998), } \\
\text { "Stationary Source } \\
\text { Emissions-- Manual } \\
\text { Method of } \\
\text { Determination of HCl-- } \\
\text { Part 1: Sampling of } \\
\text { Gases Ratified } \\
\text { European Text--Part 2: } \\
\text { Gaseous Compounds } \\
\text { Absorption Ratified } \\
\text { European Text-- Part 3: }\end{array}$ & $\begin{array}{l}\text { Part } 3 \text { of this standard cannot be considered } \\
\text { equivalent to EPA Method } 26 \text { or 26A because } \\
\text { the sample absorbing solution (water) would be } \\
\text { expected to capture both HCl and Cl2 gas, if } \\
\text { present, without the ability to distinguish } \\
\text { between the two. The EPA Methods } 26 \text { and 26A } \\
\text { use an acidified absorbing solution to first } \\
\text { separate } \mathrm{HCl} \text { and Cl2 gas so that they can be } \\
\text { selectively absorbed, analyzed, and reported } \\
\text { separately. In addition, in EN } 1911 \text { the } \\
\text { absorption efficiency for Cl2 gas would be }\end{array}$ \\
\hline
\end{tabular}




\begin{tabular}{|c|c|c|c|c|}
\hline & Agency & $\begin{array}{l}\text { Government-Unique } \\
\text { Standard }\end{array}$ & $\begin{array}{l}\text { Voluntary } \\
\text { Consensus } \\
\text { Standard }\end{array}$ & Rationale Provided by Agency \\
\hline & & & $\begin{array}{l}\text { Adsorption Solutions } \\
\text { Analysis and } \\
\text { Calculation Ratified } \\
\text { European Text" }\end{array}$ & $\begin{array}{l}\text { expected to vary as the } \mathrm{pH} \text { of the water changed } \\
\text { during sampling. }\end{array}$ \\
\hline \multirow[t]{2}{*}{42} & \multirow[t]{2}{*}{ EPA } & \multirow[t]{2}{*}{$\begin{array}{l}\text { EPA Method } 28 \text { (Section } \\
\text { 10.1) - Wood Heaters, } \\
\text { Certificate and Auditing }\end{array}$} & $\begin{array}{l}\text { ASME Power Test } \\
\text { Codes, "Supplement on } \\
\text { Instruments and } \\
\text { Apparatus, part 5, } \\
\text { Measurement of } \\
\text { Quantity of Materials, } \\
\text { Chapter 1, Weighing } \\
\text { Scales" }\end{array}$ & $\begin{array}{l}\text { It does not specify the number of initial } \\
\text { calibration weights to be used nor a specific } \\
\text { pretest weight procedure. }\end{array}$ \\
\hline & & & $\begin{array}{l}\text { ASTM E319-85 } \\
\text { (Reapproved 1997), } \\
\text { "Standard Practice for } \\
\text { the Evaluation of } \\
\text { Single-Pan Mechanical } \\
\text { Balances" }\end{array}$ & $\begin{array}{l}\text { This standard is not a complete weighing } \\
\text { procedure because it does not include a pretest } \\
\text { procedure. }\end{array}$ \\
\hline \multirow[t]{3}{*}{43} & \multirow[t]{3}{*}{ EPA } & \multirow[t]{3}{*}{$\begin{array}{l}\text { EPA Method } 29-\text { Metals } \\
\text { Emissions from } \\
\text { Stationary Sources }\end{array}$} & $\begin{array}{l}\text { CAN/CSA Z223.26- } \\
\text { M1987, "Measurement } \\
\text { of Total Mercury in Air } \\
\text { Cold Vapour Atomic } \\
\text { Absorption } \\
\text { Spectrophotometeric } \\
\text { Method" }\end{array}$ & $\begin{array}{l}\text { It lacks sufficient quality assurance and quality } \\
\text { control requirements necessary for EPA } \\
\text { compliance assurance requirements. }\end{array}$ \\
\hline & & & $\begin{array}{l}\text { ASTM D4358-94 } \\
\text { (1999), "Standard Test } \\
\text { Method for Lead and } \\
\text { Chromium in Air } \\
\text { Particulate Filter } \\
\text { Samples of Lead } \\
\text { Chromate Type } \\
\text { Pigment Dusts by } \\
\text { Atomic Absorption } \\
\text { Spectroscopy" }\end{array}$ & $\begin{array}{l}\text { These ASTM standards do not require the use of } \\
\text { glass fiber filters as in EPA Method } 12 \text { and } \\
\text { require the use of significantly different } \\
\text { digestion procedures that appear to be milder } \\
\text { than the EPA Method } 12 \text { digestion procedure. } \\
\text { For these reasons, these ASTM standards cannot } \\
\text { be considered equivalent to EPA Method } 12 \text {. } \\
\text { Also, the subject ASTM standards do not require } \\
\text { the use of hydrogen fluoride (HF) as in EPA } \\
\text { Method } 29 \text { and therefore, they cannot be used } \\
\text { for the preparation, digestion, and analysis of } \\
\text { Method } 29 \text { samples. Additionally, Method } 29 \\
\text { requires the use of a glass fiber filter, whereas } \\
\text { these three ASTM standards require cellulose } \\
\text { filters and other probable nonglass fiber media, } \\
\text { which cannot be considered equivalent to EPA } \\
\text { Method } 29 \text {. }\end{array}$ \\
\hline & & & $\begin{array}{l}\text { ASTM E1741-95 } \\
\text { (1995), "Standard } \\
\text { Practice for Preparation } \\
\text { of Airborne Particulate } \\
\text { Lead Samples } \\
\text { Collected During } \\
\text { Abatement and } \\
\text { Construction Activities }\end{array}$ & $\begin{array}{l}\text { These ASTM standards do not require the use of } \\
\text { glass fiber filters as in EPA Method } 12 \text { and } \\
\text { require the use of significantly different } \\
\text { digestion procedures that appear to be milder } \\
\text { than the EPA Method } 12 \text { digestion procedure. } \\
\text { For these reasons, these ASTM standards cannot } \\
\text { be considered equivalent to EPA Method } 12 \text {. } \\
\text { Also, the subject ASTM standards do not require }\end{array}$ \\
\hline
\end{tabular}




\begin{tabular}{|c|c|c|c|c|}
\hline & Agency & $\begin{array}{c}\text { Government-Unique } \\
\text { Standard }\end{array}$ & $\begin{array}{c}\text { Voluntary } \\
\text { Consensus } \\
\text { Standard }\end{array}$ & Rationale Provided by Agency \\
\hline & & & $\begin{array}{l}\text { for Subsequent } \\
\text { Analysis by Atomic } \\
\text { Spectrometry" }\end{array}$ & $\begin{array}{l}\text { the use of hydrogen fluoride (HF) as in EPA } \\
\text { Method } 29 \text { and therefore, they cannot be used } \\
\text { for the preparation, digestion, and analysis of } \\
\text { Method } 29 \text { samples. Additionally, Method } 29 \\
\text { requires the use of a glass fiber filter, whereas } \\
\text { these three ASTM standards require cellulose } \\
\text { filters and other probable nonglass fiber media, } \\
\text { which cannot be considered equivalent to EPA } \\
\text { Method } 29 \text {. }\end{array}$ \\
\hline & & & $\begin{array}{l}\text { ASTM E1979-98 } \\
\text { (1998), "Standard } \\
\text { Practice for Ultrasonic } \\
\text { Extraction of Paint, } \\
\text { Dust, Soil, and Air } \\
\text { Samples for } \\
\text { Subsequent } \\
\text { Determination of Lead" }\end{array}$ & $\begin{array}{l}\text { These ASTM standards do not require the use of } \\
\text { glass fiber filters as in EPA Method } 12 \text { and } \\
\text { require the use of significantly different } \\
\text { digestion procedures that appear to be milder } \\
\text { than the EPA Method } 12 \text { digestion procedure. } \\
\text { For these reasons, these ASTM standards cannot } \\
\text { be considered equivalent to EPA Method } 12 \text {. } \\
\text { Also, the subject ASTM standards do not require } \\
\text { the use of hydrogen fluoride (HF) as in EPA } \\
\text { Method } 29 \text { and therefore, they cannot be used } \\
\text { for the preparation, digestion, and analysis of } \\
\text { Method } 29 \text { samples. Additionally, Method } 29 \\
\text { requires the use of a glass fiber filter, whereas } \\
\text { these three ASTM standards require cellulose } \\
\text { filters and other probable nonglass fiber media, } \\
\text { which cannot be considered equivalent to EPA } \\
\text { Method } 29 \text {. }\end{array}$ \\
\hline 44 & EPA & $\begin{array}{l}\text { EPA Method } 101- \\
\text { Mercury Emissions, } \\
\text { Chlor-Alkali Plants (Air) }\end{array}$ & $\begin{array}{l}\text { ASTM D6216-98 - } \\
\text { Standard Practice for } \\
\text { Opacity Monitor } \\
\text { Manufacturers to } \\
\text { Certify Conformance } \\
\text { with Design and } \\
\text { Performance } \\
\text { Specifications. }\end{array}$ & $\begin{array}{l}\text { The EPA is incorporating ASTM D6216 } \\
\text { (manufacturers certification) by reference into } \\
\text { EPA Performance Specification 1, Sect. } 5 \text { \& } 6 \text { in } \\
\text { another rulemaking. ASTM D6216 does not } \\
\text { address all the requirements specified in PS- } 1 \text {. }\end{array}$ \\
\hline 45 & EPA & $\begin{array}{l}\text { EPA Method 101a - } \\
\text { Mercury Emissions - } \\
\text { Sewer/Sludge Incinerator }\end{array}$ & $\begin{array}{l}\text { ASTM D6216-98 - } \\
\text { Standard Practice for } \\
\text { Opacity Monitor } \\
\text { Manufacturers to } \\
\text { Certify Conformance } \\
\text { with Design and } \\
\text { Performance } \\
\text { Specifications. }\end{array}$ & $\begin{array}{l}\text { The EPA is incorporating ASTM D6216 } \\
\text { (manufacturers certification) by reference into } \\
\text { EPA Performance Specification 1, Sect. } 5 \text { \& } 6 \text { in } \\
\text { another rulemaking. ASTM D6216 does not } \\
\text { address all the requirements specified in PS- } 1 \text {. }\end{array}$ \\
\hline 46 & EPA & $\begin{array}{l}\text { EPA Method } 180.1- \\
\text { Turbidity, Nephelometric }\end{array}$ & $\begin{array}{l}\text { ISO } 7027 \text { - Water } \\
\text { Quality - Determination } \\
\text { of Turbidity }\end{array}$ & $\begin{array}{l}\text { EPA has no data upon which to evaluate whether } \\
\text { the separate } 90 \text { degrees scattered or transmitted } \\
\text { light measurement evaluations according to the } \\
\text { ISO } 7027 \text { method would produce results that are } \\
\text { equivalent to results produced by the other } \\
\text { methods. }\end{array}$ \\
\hline $\begin{array}{l}47 \\
*\end{array}$ & EPA & $\begin{array}{l}\text { EPA Method } 306- \\
\text { Chromium Emissions, } \\
\text { Electroplating and } \\
\text { Anodizing }\end{array}$ & $\begin{array}{l}\text { ASTM D4358-94 } \\
\text { (1999) - Standard Test } \\
\text { Method for Lead and } \\
\text { Chromium in Air }\end{array}$ & $\begin{array}{l}\text { This MACT standard (Petroleum Refineries) } \\
\text { only cites Method 29. Therefore, the following } \\
\text { EPA comment is only applicable for Method } 29 \\
\text { not Method } 12 \text { and 306: Method } 29 \text { requires the }\end{array}$ \\
\hline
\end{tabular}




\begin{tabular}{|c|c|c|c|c|}
\hline & Agency & $\begin{array}{l}\text { Government-Unique } \\
\text { Standard }\end{array}$ & $\begin{array}{c}\text { Voluntary } \\
\text { Consensus } \\
\text { Standard } \\
\end{array}$ & Rationale Provided by Agency \\
\hline & & & $\begin{array}{l}\text { Particulate Filter } \\
\text { Samples of Lead } \\
\text { Chromate Type } \\
\text { Pigment Dusts by } \\
\text { Atomic Absorption } \\
\text { Spectroscopy }\end{array}$ & $\begin{array}{l}\text { use of hydrofluoric acid (HF) in its process of } \\
\text { digestion of the sample. ASTM D4358-94 } \\
\text { (1999) does not require the use of HF; therefore, } \\
\text { it cannot be used in the preparation, digestion, } \\
\text { and analysis of Method } 29 \text { samples. } \\
\text { Additionally, Method } 29 \text { requires the use of a } \\
\text { glass fiber filter, whereas the subject ASTM } \\
\text { standard requires cellulose filters and other } \\
\text { probable non-glass fiber media, and this further } \\
\text { negates their use as Method } 29 \text { equivalent } \\
\text { methods. (Same comment as provided for } \\
\text { ASTM E1741 and ASTM E1979). }\end{array}$ \\
\hline $\begin{array}{l}48 \\
*\end{array}$ & EPA & $\begin{array}{l}\text { EPA Method 306a- } \\
\text { Chromium Emissions, } \\
\text { Electroplating-Mason } \\
\text { Jar }\end{array}$ & $\begin{array}{l}\text { ASTM D4358-94 } \\
\text { (1999) - Standard Test } \\
\text { Method for Lead and } \\
\text { Chromium in Air } \\
\text { Particulate Filter } \\
\text { Samples of Lead } \\
\text { Chromate Type } \\
\text { Pigment Dusts by } \\
\text { Atomic Absorption } \\
\text { Spectroscopy }\end{array}$ & $\begin{array}{l}\text { This MACT standard (Petroleum Refineries) } \\
\text { only cites Method 29. Therefore, the following } \\
\text { EPA comment is only applicable for Method } 29 \\
\text { not Method } 12 \text { and 306: Method } 29 \text { requires the } \\
\text { use of hydrofluoric acid (HF) in its process of } \\
\text { digestion of the sample. ASTM D4358-94 } \\
\text { (1999) does not require the use of HF; therefore, } \\
\text { it cannot be used in the preparation, digestion, } \\
\text { and analysis of Method } 29 \text { samples. } \\
\text { Additionally, Method } 29 \text { requires the use of a } \\
\text { glass fiber filter, whereas the subject ASTM } \\
\text { standard requires cellulose filters and other } \\
\text { probable non-glass fiber media, and this further } \\
\text { negates their use as Method } 29 \text { equivalent } \\
\text { methods. (Same comment as provided for } \\
\text { ASTM E1741 and ASTM E1979). }\end{array}$ \\
\hline 49 & EPA & $\begin{array}{l}\text { EPA Method } 320 \text { - Vapor } \\
\text { Phase Organic and } \\
\text { Inorganic Emissions, } \\
\text { FTIR }\end{array}$ & $\begin{array}{l}\text { ASTM D6348-98, } \\
\text { "Determination of } \\
\text { Gaseous Compounds } \\
\text { by Extractive Direct } \\
\text { Interface Fourier } \\
\text { Transform (FTIR) } \\
\text { Spectroscopy" }\end{array}$ & $\begin{array}{l}\text { Suggested revisions to ASTM D6348-98 were } \\
\text { sent to ASTM by the EPA that, would allow the } \\
\text { EPA to accept ASTM D6348-98 as an } \\
\text { acceptable alternative. The ASTM } \\
\text { Subcommittee D22-03 is currently undertaking a } \\
\text { revision of ASTM D6348- 98. Because of this, } \\
\text { we are not citing this standard as a acceptable } \\
\text { alternative for EPA Method } 320 \text { in the final rule } \\
\text { today. However, upon successful ASTM } \\
\text { balloting and demonstration of technical } \\
\text { equivalency with the EPA FTIR methods, the } \\
\text { revised ASTM standard could be incorporated } \\
\text { by reference for EPA regulatory applicability. } \\
\text { In the interim, facilities have the option to } \\
\text { request ASTM D6348-98 as an alternative test } \\
\text { method under } 40 \text { CFR 63.7(f) and 63.8(f) on a } \\
\text { case-by-case basis. }\end{array}$ \\
\hline 50 & EPA & $\begin{array}{l}\text { EPA Method } 515.1- \\
\text { Chlorinated Acids in } \\
\text { Water by GC/ECD }\end{array}$ & $\begin{array}{l}\text { Standard Methods } \\
\text { 6640B }\end{array}$ & $\begin{array}{l}\text { Standard Methods 6640B for acid herbicides } \\
\text { was tentatively deemed impractical for EPA's } \\
\text { needs because its sample preparation and quality } \\
\text { control procedures were not similar enough to } \\
\text { EPA Method } 515.1 \text { to ensure that there would } \\
\text { not be underreporting of acid herbicide }\end{array}$ \\
\hline
\end{tabular}




\begin{tabular}{|c|c|c|c|c|}
\hline & Agency & $\begin{array}{l}\text { Government-Unique } \\
\text { Standard }\end{array}$ & $\begin{array}{l}\text { Voluntary } \\
\text { Consensus } \\
\text { Standard }\end{array}$ & Rationale Provided by Agency \\
\hline & & & & $\begin{array}{l}\text { contamination. EPA plans to offer to work with } \\
\text { the Standard Methods committee to resolve this } \\
\text { issue prior to the next publication. }\end{array}$ \\
\hline \multirow[t]{2}{*}{51} & EPA & $\begin{array}{l}\text { EPA Method } 515.4- \\
\text { Chlorinated Acids in DW } \\
\text { by LL Fast CG/ECD }\end{array}$ & $\begin{array}{l}\text { ASTM D5317-98 -- } \\
\text { Standard Test Method } \\
\text { For Determination of } \\
\text { Chlorinated Organic } \\
\text { Acid Compounds in } \\
\text { Water by Gas } \\
\text { Chromatography With } \\
\text { an Electron Capture } \\
\text { Detector }\end{array}$ & $\begin{array}{l}\text { ASTM D5317-98 specifies acceptance windows } \\
\text { for the initial demonstration of proficiency for } \\
\text { laboratory fortified blank samples that are as } \\
\text { small as } 0 \text { percent to as large as } 223 \text { percent } \\
\text { recovery for picloram, with tighter criteria for } \\
\text { other regulated contaminants. Therefore, this } \\
\text { method permits unacceptably large control } \\
\text { limits, which include } 0 \text { percent recovery. }\end{array}$ \\
\hline & & & $\begin{array}{l}\text { Standard Method } 6640 \\
\text { B for the chlorinated } \\
\text { acids Standard Method } \\
6640 \text { B for the } \\
\text { chlorinated acids }\end{array}$ & $\begin{array}{l}\text { The use of this voluntary consensus standard } \\
\text { would have been impractical due to significant } \\
\text { shortcomings in the sample preparation and } \\
\text { quality control sections of the method } \\
\text { instructions. Section 1b of Method SM } 6640 \text { B } \\
\text { states that the alkaline wash detailed in section } \\
4 \mathrm{~b} 2 \text { is optional. The hydrolysis that occurs } \\
\text { during this step is essential to the analysis of the } \\
\text { esters of many of the analytes. Therefore, this } \\
\text { step is necessary and cannot be optional. In } \\
\text { addition, the method specifies that the quality } \\
\text { control limits for laboratory-fortified blanks are } \\
\text { to be based upon plus or minus three times the } \\
\text { standard deviation of the mean recovery of the } \\
\text { analytes, as determined in each laboratory. } \\
\text { Therefore, this method permits unacceptably } \\
\text { large control limits, which may include } 0 \text { percent } \\
\text { recovery. }\end{array}$ \\
\hline 52 & EPA & $\begin{array}{l}\text { EPA Method 531.2-N- } \\
\text { Methylcarbamoylozimes/ } \\
\text { ates, Aqueous In/HPLC }\end{array}$ & $\begin{array}{l}\text { Standard Method 6610, } \\
\text { 20th Edition }\end{array}$ & $\begin{array}{l}\text { Standard Method 6610, 20th Edition has recently } \\
\text { been approved for compliance monitoring. } \\
\text { Standard Method 6610, 20th Supplemental } \\
\text { Edition permits the use of a strong acid, } \\
\text { hydrochloric acid (HCL), as a preservative. The } \\
\text { preservatives in all of the other approved EPA } \\
\text { and Standard Methods procedures for these } \\
\text { analytes are weak acids that adjust the pH to a } \\
\text { specific value based upon the pKa of the } \\
\text { preservative. The use of HCL would require } \\
\text { accurate determinations of the pH of the sample } \\
\text { in the field and could be subject to considerable } \\
\text { error and possible changes in pH upon storage. } \\
\text { Although not specifically observed for oxamyl } \\
\text { or carbofuran during the development of similar } \\
\text { methods, structurally similar pesticides have } \\
\text { been shown to degrade over time when kept at } \\
\text { pH 3. Therefore, approval of this method is } \\
\text { impractical because it specifies the use of a } \\
\text { strong acid (HCL) when positive control of the } \\
\text { pH is critical. }\end{array}$ \\
\hline
\end{tabular}




\begin{tabular}{|c|c|c|c|c|}
\hline & Agency & $\begin{array}{l}\text { Government-Unique } \\
\text { Standard }\end{array}$ & $\begin{array}{c}\text { Voluntary } \\
\text { Consensus } \\
\text { Standard }\end{array}$ & Rationale Provided by Agency \\
\hline & & & $\begin{array}{l}\text { Standard Method 6610, } \\
\text { 20th Supplemental } \\
\text { Edition }\end{array}$ & $\begin{array}{l}\text { Standard Method 6610, 20th Edition has recently } \\
\text { been approved for compliance monitoring. } \\
\text { Standard Method 6610, 20th Supplemental } \\
\text { Edition permits the use of a strong acid, } \\
\text { hydrochloric acid (HCL), as a preservative. The } \\
\text { preservatives in all of the other approved EPA } \\
\text { and Standard Methods procedures for these } \\
\text { analytes are weak acids that adjust the pH to a } \\
\text { specific value based upon the pKa of the } \\
\text { preservative. The use of HCL would require } \\
\text { accurate determinations of the pH of the sample } \\
\text { in the field and could be subject to considerable } \\
\text { error and possible changes in pH upon storage. } \\
\text { Although not specifically observed for oxamyl } \\
\text { or carbofuran during the development of similar } \\
\text { methods, structurally similar pesticides have } \\
\text { been shown to degrade over time when kept at } \\
\text { pH } 3 \text {. Therefore, approval of this method is } \\
\text { impractical because it specifies the use of a } \\
\text { strong acid (HCL) when positive control of the } \\
\text { pH is critical. }\end{array}$ \\
\hline 53 & EPA & $\begin{array}{l}\text { EPA Method } 1650 \text { - } \\
\text { Organic Halides, } \\
\text { Absorbable (AOX) }\end{array}$ & $\begin{array}{l}\text { ISO, DIN, SCAN, and } \\
\text { Standard Methods (SM } \\
\text { 5320) - No Titles } \\
\text { Found }\end{array}$ & $\begin{array}{l}\text { EPA decided to use EPA Method 1650. This } \\
\text { Method was developed by drawing on various } \\
\text { procedures contained in the methods of } \\
\text { voluntary consensus standards bodies and other } \\
\text { standards developers, such as ISO, DIN, SCAN, } \\
\text { and Standard Methods (SM 5320). However, } \\
\text { none of these more narrowly focused voluntary } \\
\text { consensus standards contained the standardized } \\
\text { quality control and quality control compliance } \\
\text { criteria that EPA requires for data verification } \\
\text { and validation in its water programs. Therefore, } \\
\text { EPA found none of these VCS standing alone to } \\
\text { meet EPA's needs. }\end{array}$ \\
\hline \multirow[t]{2}{*}{$\begin{array}{l}54 \\
*\end{array}$} & EPA & $\begin{array}{l}\text { EPA Method } \\
\text { ALT } 004\end{array}$ & $\begin{array}{l}\text { ISO 10396:1993 - } \\
\text { Stationary Source } \\
\text { Emissions: Sampling } \\
\text { for the Automated } \\
\text { Determination of Gas } \\
\text { Concentrations }\end{array}$ & $\begin{array}{l}\text { Duplicates Methods 3a, 6c, 7e, 10, ALT } 004 \text { and } \\
\text { CTM } 022 \text {. Lacks in detail and quality assurance } \\
\text { plus quality control requirements. Similar to } \\
\text { ASTM D5835. }\end{array}$ \\
\hline & & & $\begin{array}{l}\text { ASTM D5835-95 - } \\
\text { Standard Practice for } \\
\text { Sampling Stationary } \\
\text { Source Emissions for } \\
\text { Automated } \\
\text { Determination of Gas } \\
\text { Concentration. }\end{array}$ & $\begin{array}{l}\text { Similar to Methods 3a, 6c, 7e, } 10 \text {, ALT } 004 \text { and } \\
\text { CTM 022. Lacks in detail and quality assurance } \\
\text { and quality control requirements. Very similar } \\
\text { to ISO } 10396 .\end{array}$ \\
\hline $\begin{array}{l}55 \\
*\end{array}$ & EPA & $\begin{array}{l}\text { EPA Method } \\
\text { CTM } 022\end{array}$ & $\begin{array}{l}\text { ISO 10396:1993 - } \\
\text { Stationary Source }\end{array}$ & $\begin{array}{l}\text { Duplicates Methods 3a, 6c, 7e, 10, ALT } 004 \text { and } \\
\text { CTM 022. Lacks in detail and quality assurance }\end{array}$ \\
\hline
\end{tabular}




\begin{tabular}{|c|c|c|c|c|}
\hline & Agency & $\begin{array}{l}\text { Government-Unique } \\
\text { Standard }\end{array}$ & $\begin{array}{c}\text { Voluntary } \\
\text { Consensus } \\
\text { Standard }\end{array}$ & Rationale Provided by Agency \\
\hline & & & $\begin{array}{l}\text { Emissions: Sampling } \\
\text { for the Automated } \\
\text { Determination of Gas } \\
\text { Concentrations }\end{array}$ & $\begin{array}{l}\text { plus quality control requirements. Similar to } \\
\text { ASTM D5835. }\end{array}$ \\
\hline & & & $\begin{array}{l}\text { ASTM D5835-95 - } \\
\text { Standard Practice for } \\
\text { Sampling Stationary } \\
\text { Source Emissions for } \\
\text { Automated } \\
\text { Determination of Gas } \\
\text { Concentration. }\end{array}$ & $\begin{array}{l}\text { Similar to Methods 3a, 6c, 7e, 10, ALT } 004 \text { and } \\
\text { CTM 022. Lacks in detail and quality assurance } \\
\text { and quality control requirements. Very similar } \\
\text { to ISO } 10396 \text {. }\end{array}$ \\
\hline 56 & EPA & EPA Method GG & $\begin{array}{l}\text { ASTM D3031-81- } \\
\text { Method of Test for } \\
\text { Total Sulfur in Natural } \\
\text { Gas (Hyrogenation), } \\
\text { Withdrawn }\end{array}$ & $\begin{array}{l}\text { This method has been deleted from the final rule } \\
\text { because it was discontinued by the ASTM in } \\
1990 \text { with no replacement. If the total sulfur } \\
\text { content of the fuel being fired in the turbine is } \\
\text { less than } 0.4 \text { weight percent, we are adding a } \\
\text { provision that the following methods may be } \\
\text { used to measure the sulfur content of the fuel: } \\
\text { ASTM D4084-82 or 94, D5504-01, D6228-98, } \\
\text { or the Gas Processors Association Method 2377- } \\
\text { 86. This provision is consistent with the } \\
\text { provision in } 40 \text { CFR 60.13(j)(1) allowing } \\
\text { alternatives to reference method tests to } \\
\text { determine relative accuracy of CEMS for } \\
\text { sources with emission rates demonstrated to be } \\
\text { less than } 50 \text { percent of the applicable standard. }\end{array}$ \\
\hline 57 & EPA & $\begin{array}{l}\text { EPA Performance } \\
\text { Specification } 1\end{array}$ & $\begin{array}{l}\text { ASTM D6216-98 - } \\
\text { Standard Procedure for } \\
\text { Opacity Monitor } \\
\text { Manufacturers to } \\
\text { Certify Conformance } \\
\text { with Design and } \\
\text { Performance } \\
\text { Specifications. }\end{array}$ & $\begin{array}{l}\text { The standard does not address all the } \\
\text { requirements specified in PS-1. }\end{array}$ \\
\hline \multirow[t]{2}{*}{58} & \multirow[t]{2}{*}{ EPA } & $\begin{array}{l}\text { EPA Performance } \\
\text { Specification } 2 \text { (nitrogen } \\
\text { oxide portion only), PF, } \\
\text { Performance } \\
\text { Specifications 1-7 }\end{array}$ & $\begin{array}{l}\text { ISO 10849:1996, } \\
\text { "Determination of the } \\
\text { Mass Concentration of } \\
\text { Nitrogen Oxides-- } \\
\text { Performance } \\
\text { Characteristics of } \\
\text { Automated Measuring } \\
\text { Systems" }\end{array}$ & $\begin{array}{l}\text { Test methods options are not specific enough to } \\
\text { meet the required regulatory levels specified } \\
\text { in Rule \# } 68 \text { FR 5144-01, } 2003 \text { (WL 201268) } \\
\text { "Federal Plan Requirements for Small Municipal } \\
\text { Waste Combustion Units Constructed On or } \\
\text { Before August 30, 1999." }\end{array}$ \\
\hline & & $\begin{array}{l}\text { EPA Performance } \\
\text { Specification } 2 \text { (sulfur } \\
\text { dioxide portion only), PF, } \\
\text { Performance } \\
\text { Specifications } 1-7\end{array}$ & $\begin{array}{l}\text { ISO 7935:1992, } \\
\text { "Stationary Source } \\
\text { Emissions-- } \\
\text { Determination of the } \\
\text { Mass Concentration of } \\
\text { Sulfur Dioxide-- } \\
\text { Performance } \\
\text { Characteristics of }\end{array}$ & $\begin{array}{l}\text { Test method options in the standard are not } \\
\text { specific or rigorous enough to meet the } \\
\text { regulatory levels specified in Rule \# } 68 \text { FR } \\
\text { 5144-01, } 2003 \text { (WL 201268) "Federal Plan } \\
\text { Requirements for Small Municipal Waste } \\
\text { Combustion Units Constructed On or Before } \\
\text { August 30, 1999." }\end{array}$ \\
\hline
\end{tabular}




\begin{tabular}{|c|c|c|c|c|}
\hline & Agency & $\begin{array}{c}\text { Government-Unique } \\
\text { Standard }\end{array}$ & $\begin{array}{l}\text { Voluntary } \\
\text { Consensus } \\
\text { Standard }\end{array}$ & Rationale Provided by Agency \\
\hline & & & $\begin{array}{l}\text { Automated Measuring } \\
\text { Methods" }\end{array}$ & \\
\hline 59 & EPA & $\begin{array}{l}\text { EPA Performance } \\
\text { Specifications } 11 \text { - } \\
\text { Particulate Matter } \\
\text { Continuous Monitoring } \\
\text { System }\end{array}$ & $\begin{array}{l}\text { ISO 10155:1995 - } \\
\text { Stationary Source } \\
\text { Emissions Automated } \\
\text { Monitoring of Mass } \\
\text { Concentration of } \\
\text { Particles - Performance } \\
\text { Characteristics, Test } \\
\text { Methods, and } \\
\text { Specifications }\end{array}$ & $\begin{array}{l}\text { This international standard is only applicable on } \\
\text { a site-specific basis by direct correlation with the } \\
\text { manual method ISO } 9096 \text { (which does not } \\
\text { produce particulate matter measurements like } \\
\text { EPA Method 5). This appears to be a particulate } \\
\text { matter (PM) CEMS performance specification } \\
\text { similar to EPA Performance Specification (PS) } \\
\text { 11, but does not contain detailed RATA } \\
\text { procedures. In addition, EPA does not have a } \\
\text { final performance specification to compare this } \\
\text { to. }\end{array}$ \\
\hline 60 & EPA & GLI Method 2 & $\begin{array}{l}\text { ISO } 7027 \text { - Water } \\
\text { Quality - Determination } \\
\text { of Turbidity }\end{array}$ & $\begin{array}{l}\text { EPA has no data upon which to evaluate whether } \\
\text { the separate } 90 \text { degrees scattered or transmitted } \\
\text { light measurement evaluations according to the } \\
\text { ISO } 7027 \text { method would produce results that are } \\
\text { equivalent to results produced by the other } \\
\text { methods. }\end{array}$ \\
\hline 61 & EPA & Standard Method 2130B & $\begin{array}{l}\text { ISO } 7027 \text { - Water } \\
\text { Quality - Determination } \\
\text { of Turbidity }\end{array}$ & $\begin{array}{l}\text { EPA has no data upon which to evaluate whether } \\
\text { the separate } 90 \text { degrees scattered or transmitted } \\
\text { light measurement evaluations according to the } \\
\text { ISO } 7027 \text { method would produce results that are } \\
\text { equivalent to results produced by the other } \\
\text { methods. }\end{array}$ \\
\hline \multirow[t]{2}{*}{62} & \multirow[t]{2}{*}{ EPA } & \multirow[t]{2}{*}{ SW846-6010b } & $\begin{array}{l}\text { ASTM C1111-98 } \\
\text { (1998) - Standard Test } \\
\text { Method for } \\
\text { Determining Elements } \\
\text { in Waste Streams by } \\
\text { Inductively Coupled } \\
\text { Plasma-Atomic } \\
\text { Emission } \\
\text { Spectrometers }\end{array}$ & $\begin{array}{l}\text { This standard lacks details for instrument } \\
\text { operation QA/QC, such as optimizing plasma } \\
\text { operating conditions; upper limit of linear } \\
\text { dynamic range; spectral interference correction; } \\
\text { and calibration procedures, which include initial } \\
\text { and continuous calibration verifications. Also } \\
\text { lacks internal standard and method of standard } \\
\text { addition options for samples with interferences. }\end{array}$ \\
\hline & & & $\begin{array}{l}\text { ASTM D6349-99 } \\
\text { (1999) - Standard Test } \\
\text { Method for } \\
\text { Determining Major and } \\
\text { Minor Elements in } \\
\text { Coal, Coke, and Solid } \\
\text { Residues from } \\
\text { Combustion of Coal } \\
\text { and Coke by } \\
\text { Inductively Coupled } \\
\text { Plasma-Atomic } \\
\text { Emission } \\
\text { Spectrometers }\end{array}$ & $\begin{array}{l}\text { This standard lacks details for instrument } \\
\text { operation QA/QC, such as optimizing plasma } \\
\text { operating conditions, upper limit of linear } \\
\text { dynamic range, spectral interference correction, } \\
\text { and calibration procedures, that include initial } \\
\text { and continuous calibration verifications. Also } \\
\text { lacks details for standard preparation, and } \\
\text { internal standard and method of standard } \\
\text { addition options for samples with interferences. }\end{array}$ \\
\hline 63 & GSA & $\begin{array}{l}\text { Federal Specification A- } \\
\text { A-1925 - Shield, } \\
\text { Expansion (Nail Anchors) }\end{array}$ & $\begin{array}{l}\text { ASTM E488- } \\
\text { Standard Test Methods } \\
\text { for Strength of } \\
\text { Anchors in Concrete } \\
\text { and Masonry Elements }\end{array}$ & $\begin{array}{l}\text { This government-unique standard is prepared \& } \\
\text { maintained by the Defense Logistics Agency } \\
\text { (DLA). Both the GSA \& DLA contract for } \\
\text { products that reference A-A-1925. In order to } \\
\text { maintain product continuity in the federal }\end{array}$ \\
\hline
\end{tabular}




\begin{tabular}{|c|c|c|c|c|}
\hline & Agency & $\begin{array}{l}\text { Government-Unique } \\
\text { Standard }\end{array}$ & $\begin{array}{l}\text { Voluntary } \\
\text { Consensus } \\
\text { Standard }\end{array}$ & Rationale Provided by Agency \\
\hline & & & & $\begin{array}{l}\text { marketplace, we must cite the standard as the } \\
\text { DLA. }\end{array}$ \\
\hline $\begin{array}{l}64 \\
*\end{array}$ & GSA & $\begin{array}{l}\text { Federal Specification } \\
\text { KKK-A-1822E - Federal } \\
\text { Specification for } \\
\text { Ambulances }\end{array}$ & $\begin{array}{l}\text { ASTM F2020 - } \\
\text { Standard Practice for } \\
\text { Design, Construction, } \\
\text { and Procurement of } \\
\text { Emergency Medical } \\
\text { Services Ambulances }\end{array}$ & 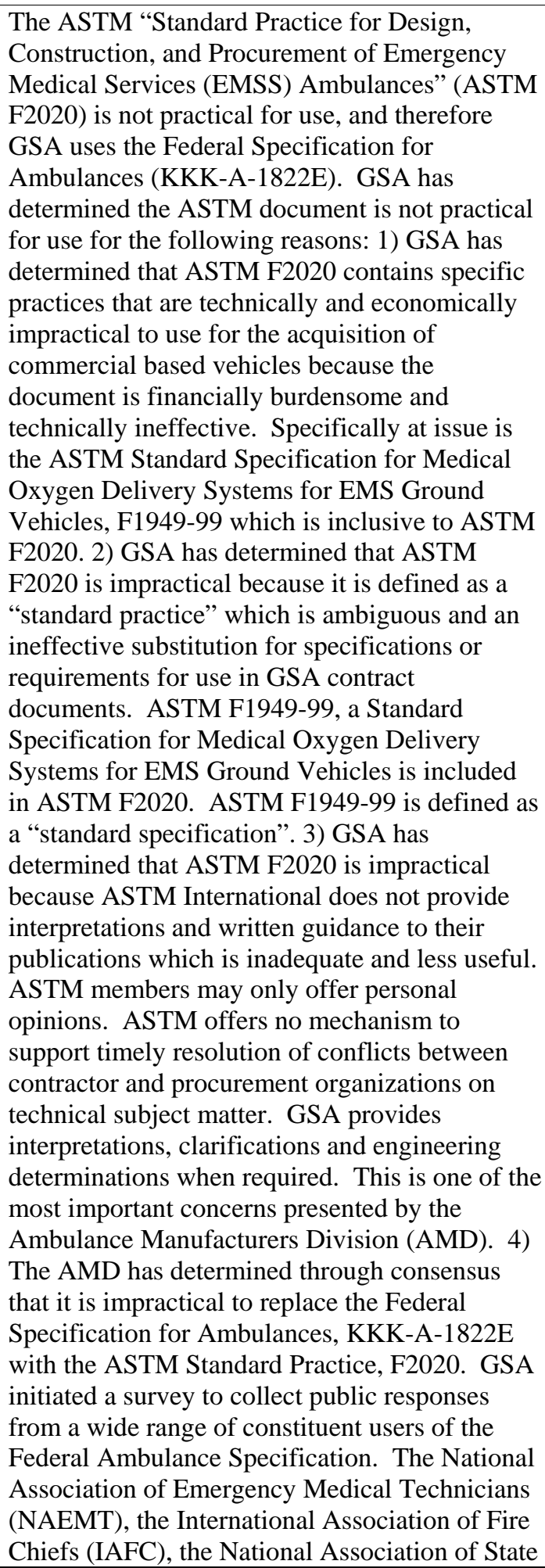 \\
\hline
\end{tabular}




\begin{tabular}{|c|c|c|c|c|}
\hline & Agency & $\begin{array}{c}\text { Government-Unique } \\
\text { Standard }\end{array}$ & $\begin{array}{c}\text { Voluntary } \\
\text { Consensus } \\
\text { Standard }\end{array}$ & Rationale Provided by Agency \\
\hline & & & & $\begin{array}{l}\text { EMS Directors (NASEMSD) and the National } \\
\text { Association of EMS Physicians universally } \\
\text { accept and support the continued use of the } \\
\text { Federal Specification. The AMD and } \\
\text { constituent users have determined that it is } \\
\text { impractical to replace the Federal Specification } \\
\text { for Ambulances, KKK-A-1822E with the ASTM } \\
\text { Standard Practice, F2020 because rule } \\
\text { promulgation is burdensome and costly. Staff } \\
\text { and administration resources would need to be } \\
\text { diverted in each state EMS office to implement } \\
\text { the change in statutes, public health codes, rules } \\
\text { and regulations. 5) GSA has determined that } \\
\text { ASTM F2020 is impractical because it is } \\
\text { burdensome to GSA procurement efforts. While } \\
\text { the current ASTM document recites many of the } \\
\text { requirements from the Federal Specification, a } \\
\text { future ASTM document would likely have } \\
\text { diverging requirements unacceptable to the } \\
\text { Government. This was verified by a member of } \\
\text { the ASTM F2020 subcommittee at the } \\
\text { September 4, } 2003 \text { meeting of the Federal } \\
\text { Interagency Committee on Emergency Medical } \\
\text { Services. }\end{array}$ \\
\hline 65 & GSA & $\begin{array}{l}\text { MIL-G-9954 - Glass } \\
\text { Beads for Cleaning and } \\
\text { Peening }\end{array}$ & $\begin{array}{l}\text { SAE/AMS } 2431 \text { - } \\
\text { Peening Media, } \\
\text { General Requirements }\end{array}$ & $\begin{array}{l}\text { This government-unique standard contains } \\
\text { specific size \& performance required for Air } \\
\text { Force critical applications that are not present in } \\
\text { the voluntary standards. }\end{array}$ \\
\hline 66 & NARA & NARA Data Standard & $\begin{array}{l}\text { Encoded Archival } \\
\text { Description (EAD) } \\
\text { Archives, Personal } \\
\text { Papers, and } \\
\text { Manuscripts (APPM) } \\
\text { General International } \\
\text { Standard Archival } \\
\text { Description (ISAD(G)) } \\
\text { International Standard } \\
\text { Archival Authority } \\
\text { Record for Corporate } \\
\text { Bodies, Persons, and } \\
\text { Families } \\
\text { (ISAAR(CPF)) } \\
\text { Machine Readable } \\
\text { Cataloguing (MARC) }\end{array}$ & $\begin{array}{l}\text { These standards do not meet the precise needs of } \\
\text { our agency. However, we continue to bring our } \\
\text { individual data elements guidance closer into } \\
\text { line with these voluntary standards. }\end{array}$ \\
\hline $\begin{array}{l}67 \\
*\end{array}$ & CPSC & $\begin{array}{l}\text { FR/Vol. 68, No. } \\
\text { 75/Friday, April 18, 2003, } \\
\text { pp. 19142-19147, "Metal- } \\
\text { Cored Candlewicks }\end{array}$ & $\begin{array}{l}\text { Voices of Safety } \\
\text { International (VOSI) } \\
\text { standard on lead in } \\
\text { candle wicks }\end{array}$ & $\begin{array}{l}\text { The U.S. Consumer Product Safety Commission } \\
\text { found that "the VOSI standard is technically } \\
\text { unsound, and thus would not result in the } \\
\text { elimination or adequate reduction of the risk, }\end{array}$ \\
\hline
\end{tabular}




\begin{tabular}{|c|c|c|c|c|}
\hline & Agency & $\begin{array}{l}\text { Government-Unique } \\
\text { Standard }\end{array}$ & $\begin{array}{l}\text { Voluntary } \\
\text { Consensus } \\
\text { Standard }\end{array}$ & Rationale Provided by Agency \\
\hline & & $\begin{array}{l}\text { Containing Lead and } \\
\text { Candles With Such } \\
\text { Wicks" }\end{array}$ & & $\begin{array}{l}\text { and that substantial compliance with it is } \\
\text { unlikely." See FR/Vol. 68, No. 75/Friday, April } \\
\text { 18, 2003, pp. 19145-19146, paragraph H2, } \\
\text { "Voluntary Standards" for further information on } \\
\text { this finding. }\end{array}$ \\
\hline 68 & CPSC & $\begin{array}{l}\text { CPSC CFR Parts 1213, } \\
1500 \text {, and } 1513\end{array}$ & $\begin{array}{l}\text { ASTM F1427-96 } \\
\text { Bunk Beds }\end{array}$ & $\begin{array}{l}\text { The CPSC rule goes beyond the provisions of } \\
\text { the ASTM voluntary standard to provide } \\
\text { increased protection to children from the risk of } \\
\text { death and serious injury from entrapment. }\end{array}$ \\
\hline 69 & GPO & FED-STD 209 & $\begin{array}{l}\text { ISO } 14644-1 \& \text { ISO } \\
14644-2\end{array}$ & $\begin{array}{l}\text { Quality Assurance. Second ISO standard not } \\
\text { issued until end of FY 2000. Being phased out. }\end{array}$ \\
\hline 70 & GPO & MIL-STD 105 & ANSI/ASQC Z1.4 & $\begin{array}{l}\text { Quality Assurance. Cited in small number of } \\
\text { contracts due to editing errors. These are being } \\
\text { corrected and phased out. }\end{array}$ \\
\hline 71 & GPO & MIL-STD 1189 & $\begin{array}{l}\text { ANSI/AIM X5-2 \& } \\
\text { ANSI X3.182 }\end{array}$ & $\begin{array}{l}\text { Quality Assurance. Cited in small number of } \\
\text { contracts due to editing errors. These are being } \\
\text { corrected and phased out. }\end{array}$ \\
\hline 72 & GPO & MIL-STD 498 & $\begin{array}{l}\text { IEEE/EIA 12207.0, } \\
\text { IEEE/EIA 12207.1, \& } \\
\text { IEEE/EIA 12207.2 }\end{array}$ & $\begin{array}{l}\text { Quality Assurance. Cited in small number of } \\
\text { contracts due to editing errors. These are being } \\
\text { corrected and phased out. }\end{array}$ \\
\hline
\end{tabular}




\section{Appendix D: The “Standards.Gov” Website}

\section{STANDARDS GOV}

National Technology Transfer and Advancement Act

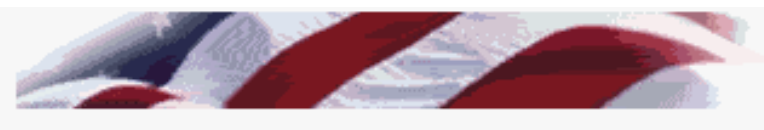

\section{Admin Help}

Looking for Standards

Governument Members on

Standards Developing

Committees

Members: Dept of Commerce

Government Standardization

Programs and Offices

Private Sector Standards

Developing Organizations

Update NTTAA Anuual Report 4

Interagency Comumittee on

Standards Policy
Standards. Gov is a one-stop location for finding information related to the use of voluntary consensus standards in government. Each federal agency web site (as well as state and local governments sites) has important, standards-related information. Locating that information can be a time-consuming and difficult task. At Standards. Gov, you can find links that take you directly to the information you want, thus reducing time and effort spent in needlessly locating and then searching numerous agency web sites.

You can find links to information about:

- laws and guidance related to government use of voluntary consensus standards

- government participation in standards developing activities

- information on standards developing organizations

Finally, through Standards. Gov you can locate and communicate directly with organizations and with individuals who are involved with standards activities, information on standards developing organizations, sources for identifying and obtaining standards documents, and much more. 